\title{
EL RECLUTAMIENTO ILICITO EN LOS PLANES DE GOBIERNO DE LOS MUNICIPIOS EL CALAMAR, RETORNO Y MIRAFLORES DEL DEPARTAMENTO DEL GUAVIARE (2012-2016)
}

Paola Mendoza Castellanos

Trabajo de grado para optar el título de magister en derechos humanos y DIH

Directora

Ana María Jiménez

Universidad Santo Tomás

Facultad de derecho

Maestría Defensa de los Derechos Humanos y el Derecho Internacional Humanitario ante organismos, cortes y tribunales internacionales Bogotá D.C. 2018

EL RECLUTAMIENTO ILICITO EN PLANES DE GOBIERNO DE LOS MUNICIPIOS EL CALAMAR, 


\section{RETORNO Y MIRAFLORES DEL DEPARTAMENTO DE GUAVIARE \\ (2012-2016)}

Paola Mendoza Castellanos

Universidad Santo Tomás

Facultad de derecho

Maestría Defensa de los Derechos Humanos y el Derecho Internacional Humanitario ante organismos, cortes y tribunales internacionales Bogotá D.C.

2018

NOTA DE ACEPTACIÓN 
Jurado

Jurado

Bogotá D.C., agosto de 2018.

\section{DEDICATORIA}

A Dios, por ser mi guía y porque sin su voluntad no hubiera podido alcanzar este triunfo.

A los docentes por su dedicación, empeño y transmisión de su conocimiento y 
experiencia.

A mis compañeros de maestría, por compartir momentos de penurias, alegrías y triunfos.

A mi familia, quienes son mi fuente de inspiración.

\section{Contenido}

1. INTRODUCCIÓN

2. PLANTEAMIENTO DEL PROBLEMA 9

2.1. Descripción del problema

2.2. Formulación de la pregunta de investigación. $\quad 14$

2.3. Objetivos 14 
$\begin{array}{ll}\text { 2.3.3. Objetivos Específicos } & 14\end{array}$

3. MARCO TEÓRICO 15

3.1. Antecedentes 15

3.2. Estado del arte. 16

$\begin{array}{ll}\text { 3.3. Marco Conceptual } & 17\end{array}$

3.4. Marco jurídico 19

4. METODOLOGIA DE LA INVESTIGACIÓN 22

4.1. Diseño metodológico. $\quad 22$

4.2. Fuentes de investigación 23

4.2.1 Primarias $\quad 23$

$\begin{array}{ll}\text { 4.2.2 Secundarios } & 24\end{array}$

5. RESULTADOS 24

5.1. Reclutamiento ilícito de NNA por grupos al margen de la ley en Colombia 24

5.1.1. El reclutamiento forzado de niños, niñas y adolescentes. 26

5.1.2. Formas de reclutamiento 31

5.1.4. Mecanismos para el reclutamiento y la utilización de NNA por los grupos ilegales en Colombia. $\quad 35$

5.1.5. Grupos en que son reclutados los NNA en Colombia. 37

5.1.6. Acciones ilegales específicas a las que son sometidos NNA víctimas de reclutamiento y utilización $\quad 39$

5.2. POLÍTICA PÚBLICA DE PREVENCIÓN DEL RECLUTAMIENTO ILICITO EN COLOMBIA $\quad 40$

5.2.1. Concepto 40

5.2.2. Antecedentes del diseño de la política pública de prevención del reclutamiento ilícito de NNA. $\quad 42$

5.2.3. Documento 3673 de $2010 \quad 47$

5.2.4. Rutas de Prevención $\quad 50$

5.3. Lineamientos de la política pública para la prevención del reclutamiento en los departamentos y municipios en Colombia. $\quad 52$ 
5.4. PLANES DE GOBIERNO DE LOS MUNICIPIOS DE CALAMAR, EL RETORNO

Y MIRAFLORES DEL DEPARTAMENTO DE GUAVIARE EN MATERIA DE

RECLUTAMIENTO ILEGAL DE NNA.

5.4.1. Situación actual en materia de reclutamiento de NNA en el Departamento de

Guaviare.

5.4.2. Factores y riesgos que inciden en el reclutamiento ilícito de NNA en los municipios de Calamar, Miraflores y Retorno del Departamento de Guaviare.

5.4.3. Planes de gobierno existentes durante el periodo de 2010 a 2015 para la prevención del reclutamiento ilícito de NNA en los Municipios de Calamar, Retorno y Miraflores.

5.4.2. Diagnóstico de la política pública en materia de prevención del reclutamiento ilícito de NNA en los Municipios de Calamar, el Retorno y Miraflores del Departamento de Guaviare.

5.5. Hipótesis

BIBLIOGRAFÍA

\section{LISTADO DE TABLAS Y GRÁFICOS}

Tabla No. 1

Tabla No. 2

Tabla No. 3

Tabla No.4

Gráfico No. 1
Pág. 35

Pág. 60

Pág. 61

Pág. 62

Pág. 63 


\section{LISTADO DE ABREVIATURAS}

NNA: Niños, niñas y adolescentes.

ICBF: Instituto Colombiano de Bienestar Familiar.

RUV: Reclutamiento y utilización de víctimas.

UARIV: Unidad para la atención y reparación integral a las víctimas.

SAT: Sistema de amenaza total.

FARC: Fuerzas armadas revolucionarias de Colombia.

ELN: Ejército de liberación nacional.

RNI: Red nacional de información de la unidad de víctimas.

ONG: Organización no gubernamental.

DDHH: Derechos humanos.

EAI: Equipo de acción inmediata.

\section{Resumen}

En los planes de gobierno de los municipios de Calamar, Miraflores y el Retorno del Departamento de Guaviare, existen pocos capítulos referentes a la prevención del reclutamiento ilegal de NNA, durante el periodo comprendido del 2012 a 2016. Estos no se adaptan a las políticas nacionales establecidas por factores como: falta de información de la problemática, desarticulación de los organismos competentes que manejan la misma, estructura política deficiente, poco interés de los gobernantes en implementarla, escaso avance en la creación de planes que busquen proteger los derechos fundamentales de esta población o su restablecimiento como lo establece el Código de Infancia y Adolescencia y el bloque de constitucionalidad. Tan sólo se evidencia en el Municipio de Guaviare, la elaboración del plan de prevención y atención de reclutamiento forzada con enfoque diferencial 2014- 2015.

Palabras clave: articulación, deficiencias, implementación, políticas públicas.

\section{Summary}


In the government plans of the municipalities of Calamar, Miraflores and the Return of the Department of Guaviare, there are few chapters referring to the prevention of illegal recruitment of children, during the period from 2012 to 2016. These do not adapt to national policies established by factors such as: lack of information on the problem, dismantling of the competent bodies that handle it, poor political structure, little interest of the governments in implementing it, little progress in the creation of plans that seek to protect the fundamental rights of this population or its restoration as established by the Code of Childhood and Adolescence and the constitutionality block. It is only evident in the Municipality of Guaviare, the elaboration of the plan of prevention and attention of forced recruitment with differential approach 2014-2015.

Keywords: articulation, deficiencies, implementation, public policies.

\section{1. INTRODUCCIÓN}

Colombia desde hace muchos años ha sufrido una de las prácticas más atroces y lesivas a los derechos fundamentales del ser humano como lo es el reclutamiento y la utilización de NNA con la finalidad de hacerlos parte del conflicto armado interno, colocando en riesgo su integridad, violando sus derechos a tener una familia, a la libertad, a la vida digna, a la educación, entre otros, desquebrajando su integridad física y psicológica, y con ello destruyendo sus proyectos de vida.

Según datos de Amnistía Internacional de 2008, se estima que en Colombia hay entre 8.000 y 13.000 niños y niñas soldados, con edades promedio de 13 años, los cuales, según el Secretario General de las Naciones Unidas provinieron de 29 de los 32 departamentos del país en el año 2011 (Asamblea General del Consejo de Seguridad de las Naciones Unidas. 2012).

Un gran número de mujeres, hombres, niñas y niños se han unido a los grupos al margen de la ley, en razón a diferentes factores como el desempleo, la pobreza, la desintegración familiar, por mecanismos de violencia o políticos, ausencia del Estado, entre otros.

En nuestro ordenamiento jurídico actual, se tiene definido que los derechos y garantías de los niños, niñas y adolescentes prevalecen sobre cualquier otro derecho y desde esta perspectiva resulta de vital importancia que se estudie la forma de como el Estado atiende la problemática del reclutamiento de menores, pues dentro de un contexto de conflicto armado se generan grandes riesgos, amenazas y vulnerabilidades al goce efectivo de los derechos de los NNA conllevando a plantear un modelo de atención formación, orientación y coordinación entre las mismas 
instituciones (Colombia, Corte Constitucional, 2009, Sentencia C-240, M.P. González Cuervo M., Bogotá).

Bajo estos argumentos, resulta necesario que se realicen estudios que analicen la efectividad de las estrategias que se están utilizando por el gobierno para mitigar el reclutamiento forzado, por ser su obligación el erradicar esta problemática atendiendo las disposiciones en esta materia, observando si dentro de las actuaciones desarrolladas por las Instituciones Gubernamentales influyen, fomentan o favorecen esta práctica en aras de generar un impacto positivo en las garantías de los derechos de los niños, niñas y adolescentes que hacen parte del conflicto armado, por cuanto actualmente no existen datos concretos, generales, consolidados y precisos sobre esta temática.

Igualmente, al contrastar la realidad de las circunstancias que rodean este fenómeno y al indagar sobre el desenvolvimiento de las estrategias utilizadas implementadas por el Estado es que se podrá definir si hay efectividad o no de tales estrategias esenciales en regiones que por su distanciamiento territorial y su poca o limitada estructura institucional puede verse afectada en mayor o menor medida como es el caso de los municipios de Calamar, el Retorno y Miraflores en el Departamento de Guaviare, siendo este el enfoque de esta monografía.

Lo anterior cobra especial relevancia dentro del escenario de violencia nacional, en donde el conflicto armado proyecta sus efectos en diferentes zonas del territorio y con distintos actores, provocando una situación de alto riesgo para los menores ante las variadas posibilidades en que puedan terminar involucrados, directa o indirectamente, en el desarrollo de las hostilidades.

Por ello, entendiendo la importancia de esta temática, más aun con el actual desarrollo del proceso de paz, la presente investigación centró su interés en estudiar las estrategias existentes para la prevención del reclutamiento de menores de edad por causa del conflicto armado dentro del marco jurídico y político, concentrando su enfoque en las estrategias públicas con destino en los municipios de Calamar, Retorno y Miraflores de la Gobernación de Guaviare dentro del período comprendido de 2010 a 2016, tomando como referencia el documento CONPES 3673 de 2010 que forma parte fundamental de los instrumentos que sirven para garantizar la protección de los Derechos Humanos.

El desarrollo temático del presente trabajo investigativo, se encuentra compuesto en tres capítulos, los cuales se basan en las fuentes de derecho formal, y documentos, revistas, publicaciones, investigaciones que han tratado este atroz fenómeno social en nuestro país.

El primer capítulo, de manera descriptiva trata la temática de los factores de vulnerabilidad, factores de riesgo, mecanismos, grupos, acciones, actores, 
consecuencias, clases, características del reclutamiento ilícito de NNA en Colombia.

El segundo capítulo se realiza una reseña del marco político - jurídico en el ámbito nacional para la prevención del reclutamiento de menores en Colombia.

En el tercer capítulo, se busca determinar la existencia o no de estrategias dentro del marco de la política pública para la prevención del reclutamiento de niños, niñas y adolescentes en los Municipios de Calamar, Retorno y Miraflores del Departamento de Guaviare, dentro de lapso de tiempo comprendido entre 2010 a 2016.

Por último, se exponen las principales conclusiones de la labor investigativa tendientes a demostrar si fue positiva la respuesta o no a la pregunta base del presente trabajo, de lo cual se resalta con fundamento en la información recopilada, que a pesar de que a nivel nacional existe una evolución en el desarrollo de la política pública en esta materia, en lo que refiere a la región del departamento de Guaviare, es escaso el avance que se ha tenido, por diferentes causas, siendo la más palpables la poca presencia del Estado en estos municipios, precarios recursos económicos y humanos que permitan desarrollar estrategias de mitigación del fenómeno, inexistencia de un modelo de medición de riesgos que asocie estadísticamente la magnitud de la problemática, los paradigmas del actual proceso de paz, débil desarrollo económico y social, presencia de grupos armados al margen de la ley en la región, conflictos entre los habitantes por el manejo de los recursos naturales, poco acceso a los servicios públicos esenciales, vías de transporte y comunicación ambiguas y distantes, sumado al desinterés de los gobiernos territoriales en la implementación local de la política pública que se encuentra definida para que sea adoptada en los diferentes planes de gobierno.

Conforme lo expuesto, la presente investigación tiene por finalidad, adquirir una comprensión integral del objeto de estudio, teniendo en cuenta los criterios legales, doctrinales y jurisprudenciales, y con ello, ampliar los conocimientos desde un punto de vista dogmático y conceptual, partiendo de la realidad jurídica actual para dar respuesta a la pregunta de investigación, en la que se hizo uso de la metodología conocida como teórico documental descriptiva a partir del análisis y evaluación de la política nacional y regional en esta materia.

\section{PLANTEAMIENTO DEL PROBLEMA}

\subsection{Descripción del problema}

Por décadas el conflicto armado interno en Colombia ha afectado los aspectos 
político, económico y social, generando en la población inseguridad, pobreza, falta de oportunidades para estudiar y trabajar, intolerancia, incomprensión, y el incremento de la violencia intrafamiliar, situación que pone en desventaja a los niños, niñas y adolescentes por ser sujetos vulnerables en la sociedad, cercenando oportunidades para desarrollar proyectos de vida, sueños, metas, objetivos entre otros, situaciones que permiten a los grupos organizados al margen de la ley - GAOML, aprovechen estas circunstancia para realizar actividades tendientes al reclutamiento ilícito de niños niñas y adolescentes.

Este flagelo de nuestra sociedad ha aumentado considerablemente en estos últimos cinco años, sin embargo, no es posible lograr determinar un número preciso de NNA reclutados ilícitamente ya que ha sido un trabajo complejo, pues no se cuenta con cifras exactas sobre cuántos niños han sido reclutados por las instituciones competentes para atender este fenómeno delincuencial.

Teniendo en cuenta, el informe presentado por Natalia Springer y la información del Instituto Colombiano de Bienestar Familiar - ICBF- se deduce que "no menos de 18000 niños, niñas y adolescentes están involucradas y forman parte de estos grupos armados ilegales" lo que indica que la cantidad de niños que hacen parte del combate o que son combatientes cambia de acuerdo a las estructuras a la que hagan parte. Así mismo, es de indicar que de acuerdo al informe anteriormente expuesto el $42 \%$ de pie de fuerza de las FARC-EP y el 44\% por ciento del ELN son niños". (Comparar Springer, Natalia. Como corderos entre lobos. Del uso y reclutamiento de niñas, niños y adolescentes en el marco del conflicto armado y la conspiración criminal en Colombia, 2012. p. 17.).

Según este informe, el impacto es de raigambre en los grupos poblacionales más vulnerables generando consecuencias a nivel físico, emocional, social, económico y comunitario para los niños, niñas y adolescentes afectando su relación e interacción con sus familias y su entorno (Corte Constitucional, Sentencia C-240/09, M.P. Dr. Mauricio González Cuervo).

El ICBF ha venido atendiendo a las víctimas del reclutamiento y utilización de NNA por los GAOML, aportando las bases técnicas con participación de Comité Intersectorial para la Prevención, sobre las cuales creó el programa denominado generaciones, focalizado a más del $95 \%$ de los municipios que presentan alto riesgo de reclutamiento y utilización de NNA.

Esta entidad a nivel nacional realizó un análisis con la finalidad de identificar los factores y riesgos en torno a la categoría social por género en materia conflicto armado en nuestro país, como son: la diferencia de género entre la población desmovilizada y desvinculada por parte de las GAOML, atendiendo que de acuerdo a información por parte de las ARC del 2003 al 2011: se estableció que existe un mayor porcentaje de mujeres desvinculadas que desmovilizadas lo contrario con el personal masculino (ICBF, Cartilla Observatorio del Bienestar de la Niñez No. 9, 
2013).

Por otro lado, se realizó un análisis sobre las diferencias entre las razones de reclutamiento de niños y niñas desvinculados de GAOML lo que determinó que no solo es el gusto por dinero, maltrato social o gusto por las armas, sino que hay otros factores por los cuales los GAOML están engrosando sus filas. El ICBF determinó diferencias de género en el reclutamiento de NNA, de acuerdo a la vulnerabilidad de la población, es decir, son más propensas las mujeres indígenas desvinculadas, que las mujeres de la zona rural desvinculadas y desmovilizadas, lo que conlleva que los NNA indígenas sean en un mayor grado objeto de reclutamiento por los GAOML, al residir en zonas apartadas de las cabeceras municipales (ICBF, Cartilla Observatorio del Bienestar de la Niñez, 2012).

A nivel departamental, Guaviare presenta características especiales que permiten o facilitan el reclutamiento de NNA, con una incidencia más marcada en comparación con otros departamentos de nuestro país ya que se ubica en el suroriente del país, esta zona comprende la sabana tropical en el norte y el bosque húmedo tropical en el sur, se ubica entre los llanos y la selva, grandes ríos surcan su geografía convirtiéndose en sus vías de comunicación como son las fuentes hídricas como el Guayabero, Guaviare, Inírida, Papañaua, Vaupés, y Apaporis, también es sector productivo de ganadería, cultivo de caucho, madera, pesca entre otros, en consecuencia el sector primario y el red vial se encuentran en niveles bajo a comparación de otros departamentos (Gobernación de Guaviare, Plan de Desarrollo Departamental Así Marcamos Huella, 2012-2015).

A Nivel Municipal, Calamar, el Retorno y Miraflores según el Comité Intersectorial para la prevención del reclutamiento de las NNA, "se encuentran en especial condición de riesgo y vulnerabilidad cerca de 1.800 NNA matriculados en las instituciones educativas, por la posibilidad que se presente este fenómeno del reclutamiento por las FARC, por otro lado, ha sido escaso del desarrollo urbano, al predominar las zonas rurales. Existen una reserva forestal, parques naturales y resguardos indígenas, generando tensión entre el manejo de la economía, la protección del medio ambiente, el desarrollo de las comunidades indígenas y afro ascendientes, y colonos. Se observa la desactualización de los planes de ordenamiento territorial municipales que conducen a la no optimización del uso de zonas de reserva natural, forestal, productivas, agroforestales y turísticas. Predominan las lluvias que afectan del desarrollo rural del departamento (Secretaria Técnica de la Comisión Intersectorial para la prevención del reclutamiento, la utilización y la violencia sexual contra niños, niñas y adolescentes por parte de grupos armados al margen de la ley y grupos delictivos organizados, 2015).

La productividad y el desarrollo económico es bajo teniendo en cuenta que es lenta la transición de los cultivos ilícitos a la economía de cultivos tradicionales lícitos, haciendo presencia en esta región del país los grupos al margen de la ley por causa del narcotráfico. También hay déficit de vivienda, dispersión geográfica de la 
población y de la infraestructura de los recursos sociales básicos (educación, salud, trabajo).

Según información estadística del Instituto Colombiano de Bienestar Familiar en el Departamento del Guaviare al parecer 102 niños, manifestaron haber sido reclutados por grupos irregulares en este departamento. Los menores desvinculados de los grupos armados fueron atendidos por el ICBF desde el año 1999 hasta el 31 de marzo de 2013, la entrega se ha presentado de manera voluntaria través de la fuerza pública en los puestos de control establecida en los municipios del Guaviare (Caracol, Informe de noticias, 2015). De igual forma, se tiene conocimiento que acuerdo a los últimos informes reportados por la Secretaría Técnica de la Comisión Intersectorial en el Departamento de Guaviare estaría arrojando un índice de Nivel Superior Alto de probabilidades entre los años 2010 al 2015 de casos de reclutamiento ilícito de niños, niñas y adolescentes en los Municipios de Calamar, el Retorno y Miraflores, problemática que se ha venido dando muchos años atrás con el delito del Reclutamiento de NNA por parte de los grupos organizados al margen de la ley (Secretaria Técnica de la Comisión Intersectorial, Cartilla Estrategias para la focalización de acciones: Insumos para la prevención del Reclutamiento y la violencia Sexual, 2015).

Así mismo, en materia de reclutamiento de niños, niñas y adolescentes, los grupos al margen de la ley ejercen presión sobre esta población con mentiras o amenazas para que formen parte del conflicto, siendo el índice en un mayor porcentaje como factor de reclutamiento, las edades que oscilan entre los 7 y 17años, con un promedio de edad de ingreso entre 13.8 a 12.8 años durante los cuatro últimos años al 2007 (Coalico, 2007, Informes sobre la situación de niños, niñas y jóvenes vinculados al conflicto armado en Colombia falencias en el proceso de desvinculación de niños, niñas y jóvenes de los grupos paramilitares”, P 9).

La razón de este descenso es debido a que los grupos armados ven a los niños como reclutas maleables, es decir, se adaptan fácilmente a las condiciones que se viven en las diferentes zonas desde las cuales operan los grupos armados ilegales, los niños están dispuestos a correr riesgos sin medir las consecuencias y aprenden mucho más rápido que cualquier recluta de mayor de edad (Comparar Acciones por los derechos del niño. "Niños, niñas y adolescentes vinculados al conflicto armado" 2004 P12).

Un segundo factor menos importante para el reclutamiento, es conocido como la "Voluntariedad" de la decisión ya que muchos menores que se incorporan a las filas lo hacen aparentemente por una decisión voluntaria sin que ningún factor externo fuerce esta decisión (Corte Constitucional “Auto 251” 2008. P 41).

Así mismo, los niños estarían siendo contactados por los integrantes de los grupos al margen de la ley, como es el caso de una menor víctima que contó la forma como varios de sus amigos del barrio fueron presionados para formar parte del 
conflicto, como los grupos al margen de la ley se aprovechan de los adolescentes cuando se percatan que tienen problemas en sus hogares; muchos no quieren estudiar porque se encuentran sumergidos en la drogadicción o debido a su situación económica y por lo tanto se ven obligados a ingresar a dichos grupos, este es el momento en que estos grupos se aprovechan y con mentiras y amenazas los reclutan, advirtiendo que si no se adhieren a sus filas, los que van a pagar las consecuencias son los miembros de sus familias. (Espectador, abril de1996).

Una vez dentro del grupo, la cotidianidad de los niños, niñas y adolescentes cambia completamente, "Su rol de hijo, hermano, niños o adolescentes van cambiando a una nueva clase de vida que implica formas de interacción distintas, roles diferentes y nuevas expectativas" (Romero Picón. El juego de la guerra, niños, niñas y adolescentes en el conflicto armado en Colombia $p$ 203.). A partir de este momento son sometidos a un proceso de alineación a través de las GAOML a través de constantes entrenamientos perdiendo sus instintos emocionales.

Dentro del informe presentado por Natalia Springer, como corderos entre lobos se enuncian las tres fases dentro del proceso de entrenamiento: proceso de adaptación, adoctrinamiento y endurecimiento emocional y la fase de servidumbre (Constrastar Springer. Como corderos entre lobos. Del uso y reclutamiento de niñas, niños y adolescentes en el marco del conflicto armado y la conspiración criminal en Colombia $p$ 21). Y en ningún caso, en el reclutamiento media la voluntad de los niños y niñas aun en los casos que se ve facilitado por la vulnerabilidad social y económico de los aquí afectados.

Sobre esta temática hay un fuerte debate internacional. Algunos autores señalan la voluntad individual como factor real en las decisions de niños y adolescentes de afiliarse a grupos armados ilegales, por ejemplo Brett, R. (diciembre, 2003); Schmidt, A. (2007) y Ah-Jung Lee, A.-J. (2009). Otros coinciden que en muchos casos puede haber un cierto elemento de iniciativa de parte de los niños y adolescentes, pero que en realidad existe una línea muy delgada entre la participación "voluntaria" y la coercitiva (Goodwin-Gill, G, y Cohn, I. (1994), porque los niños y las niñas no cuentan con el criterio para tomar decisiones de esta envergadura (Singer, P.W., Children at War, op.cit., pp. 61-62) y muchas veces se ven obligados a ingresar a estos grupos para escapar de las pésimas circunstancias de su entorno (Landau, D.,2001), Morini, C. (2010).

La normatividad vigente, en particular la Ley de Victimas y Restitución de Tierras, reconoce la extrema alienación en la que viven las comunidades en las que se expresa de peor manera el conflicto. De acuerdo a los anteriores conceptos, lo que se quiere buscar en este producto de investigación es lograr identificar la existencia o no de proyectos, programas y estrategias públicas de los planes de gobierno de los Municipios de Calamar, el Retorno y Miraflores, tendientes a la mitigación del reclutamiento de niños, niñas y adolescentes por parte de los grupos armados organizados al margen de la Ley durante el período comprendido de 2010-2016. 


\section{2.2. Formulación de la pregunta de investigación.}

¿Existen planes, programas, proyectos, estrategias públicas dentro del período comprendido entre los años 2.010 al 2.016 destinadas a mitigar el reclutamiento por parte de los grupos armados al margen de la ley de niños, niñas y adolescentes en el departamento del Guaviare dentro de la población que conforman los municipios de Calamar, el Retorno y Miraflores?

\subsection{Objetivos}

\subsubsection{Objetivo General}

Identificar si en los planes de gobierno de los municipios de Calamar, Miraflores y el Retorno del Departamento de Guaviare, existen capítulos referentes a la prevención del reclutamiento ilegal de NNA, durante el periodo de 2012 a 2016.

\subsubsection{Objetivos Específicos}

Determinar cuáles son los factores de vulnerabilidad, factores de riesgo, mecanismos, grupos, acciones, actores, consecuencias, clases, características del reclutamiento ilícito de NNA en Colombia.

Describir el marco político y jurídico en el ámbito nacional para la prevención del reclutamiento de NNA en Colombia a partir de la expedición del documento COMPES 3673 del 2010.

Establecer cuales capítulos dentro de los planes de gobierno de los municipios de Calamar, Miraflores y el Retorno del Departamento de Guaviare durante el periodo de tiempo años 2012 a 2016, tratan la temática de la prevención del reclutamiento ilícito de NNA.

\section{MARCO TEÓRICO}

\subsection{Antecedentes}


La presencia de los menores de edad en la guerra, tienen como referente histórico en Colombia la época de la independencia, cuando a manera temprana existía la presencia de niños en los ejércitos libertadores. Su participación en la guerra les ofrecía el escenario perfecto para que desempeñaran el rol de soldados, lo que conllevaba adquirir un estatus dentro de las filas, el cual no lograban dentro de las comunidades a la cual pertenecían.

"El sentirse importantes iba más allá de su condición de obreros, mestizos o esclavos, podría representar, por qué no, una forma de escapar del maltrato, una vida llena de aventuras para conocer nuevas formas de vida, nuevos lugares y personas, "jugar a ser combatiente”, "jugar a ser". (Carmona \& Tobón, 2006, p. 84).

El caso más sonado es el de Pedro Pascasio Martínez (1807-1885), conocido como el soldado niño o el infante soldado, muchacho que se vinculó a la edad de 12 años al batallón Rifles y a esa edad participó en las batallas del Pantano de Vargas y Boyacá. En esta última, se hizo célebre por la captura del coronel español José María Barreiro (A la Memoria, 1883). Allí Bolívar lo ascendió a sargento.

Cuando se logra la libertad de nuestro territorio, emerge diversas guerras civiles como resultado del conflicto político en Colombia el cual se remonta al siglo XIX ante la rivalidad entre los partidos tradicionales desembocando el hecho histórico de la Guerra de los Mil días y dando inicio a un periodo de violencia y guerra.

Durante el siglo XIX y parte del siglo XX, los partidos políticos tradicionales (liberales, conservadores) recurrieron a la violencia como medio para alcanzar el poder, llegando esta disputa a su nivel más crítico en el período denominado como la violencia (1946- 1958), traduciéndose el conflicto político en una abierta confrontación armada.

La confrontación política bipartidista se radicalizó y se degradó a tal punto que las agrupaciones armadas cometieron masacres, actos violentos con sevicia, crímenes sexuales, despojo de bienes y otros hechos violentos con los cuales "castigaban" al adversario. Rituales macabros, como el descuartizamiento de hombres vivos, las exhibiciones de cabezas cortadas y la dispersión de partes de cuerpos por los caminos rurales eran latentes. (Uribe, 2004).

La doctrina nacional ha propuesto diversas causas como desencadenantes del conflicto armado en el país: en las zonas de colonización hubo espacio para ejércitos no estatales; el Frente Nacional acabó con la violencia, pero dejó remanentes de guerrilla social campesina; las organizaciones guerrilleras y los paramilitares acabaron en la periferia; en Colombia no se dieron las condiciones clásicas para el triunfo de la insurgencia; el Estado fracasó en prevenir y resolver el conflicto; y la clase dirigente no articuló una respuesta desde el centro de la política. (Nullvalue, 2016). 
En la época moderna, al aparecer el fenómeno del narcotráfico, vino encrudecer la situación, al incidir en diversos aspectos del país, afectando principalmente a la población más vulnerable como las mujeres, ancianos, niños y personas discapacitadas.

\subsection{Estado del arte.}

Al consultar proyectos de investigación, artículos científicos, teorías, tesis, dentro de la literatura de esta temática, encontramos:

- Bejarano García Irma, (2015) Responsabilidad Internacional del Estado Colombiano por reclutamiento ilícito de menores durante la zona de distención, Irma, Monografía, Universidad Santo Tomás, Maestría en Defensa de los Derechos Humanos y Derecho Internacional Humanitario ante organismos internacionales y la Corte Penal Internacional, Bogotá.

- Castellanos Santos Susan Brigite, (2013), Análisis del reclutamiento forzado a menores de edad en Colombia 2005-2010, Monografía de Grado. Universidad Colegio Mayor de Nuestra Señora del Rosario, Facultad de Ciencia Política y Gobierno, Bogotá.

-Ramírez Barbosa Paula Andrea, (2010), el reclutamiento de menores en el conflicto armado colombiano. Aproximación al crimen de guerra, Artículo publicado en la Revista Derecho Penal y Criminología No.90 Vol. XXXI, enero-junio, pág. 115-116.

\subsection{Marco Conceptual}

En Colombia la problemática de los grupos armados al margen de la ley existe desde hace más de cinco décadas, siendo en la actualidad sus principales actores el Ejército de Liberación Nacional ELN", las Fuerzas Armadas Revolucionarias de Colombia "FARC", los paramilitares y los grupos urbanos de crimen organizado, convirtiéndose en un factor muy influyente en las crisis económicas, sociales y políticas del país.

Según Yaffe (2011), las causas más importantes son: i.) las causas económicas, ii.) las causas políticas e institucionales y iii.) las causas sociales y culturales. Esta autora realizó una amplia revisión y análisis de las principales teorías que explican el 
conflicto, y lo aterrizó al caso colombiano. Ella sostiene que las causas económicas se explican por dos teorías: i.) el resentimiento, la desigualdad y la injusticia, por un lado, y ii.) la codicia por el otro. Asimismo, las causas políticas se dividen en aquellas explicadas por la falta de presencia estatal y la inclusión política. Por último, las causas culturales se basan en el argumento de que los colombianos tenemos el conflicto como principal medio de solución de diferencias, el cual es consecuente con las diferentes guerras civiles sucedidas durante el siglo XIX, que tenían como objetivo resolver diferencias entre puntos de vista de la élite colombiana (Medina, 2009).

De otra parte, Bejarano (1997) y Gaitán (1995) han mostrado que los niveles más intensos de violencia en el país se localizan geográficamente en zonas de creciente riqueza agropecuaria, minera $y$ en torno a los cultivos ilícitos. Paradójicamente las zonas en donde existe poca presencia institucional del Estado, en donde más se han venido consolidando los grupos armados al margen de la ley a través del tiempo, siendo impuesto un orden civil con enfoque autoritario.

Las fuentes de financiación de sus actividades más significativas son el narcotráfico, el secuestro extorsivo, la prostitución, sin desconocer que existen otros medios utilizados para obtener dichos recursos, como lo son la extorsión, lavado de activos, minería ilegal, reclutamiento, concesiones para permitir el paso de los oleoductos, entre otros.

Los alistamientos se realizan mediante el reclutamiento de civiles entre los cuales incluyen a niños, niñas y adolescentes. En cuanto a los procesos de expansión y consolidación de sus estrategias militares, utilizan el elemento ideológico para sustentar su accionar violento (pobreza, desempleo, salud, educación, etc.), como medio para obtener recursos financieros que garanticen su supervivencia (boleteo, extorción, secuestros, asaltos a entidades financieras, etc), También hacen uso del elemento de apoyo social a sus ideales de transformación del orden social para redefinir sus estrategias militares con el fin de incursionar en territorios marginales (rurales o urbanos) mediante la inscripción y reclutamiento forzado de hombres, mujeres e infantes (Springer, 2012, pág. 8 al 11).

La presencia de los niños, niñas y adolescentes en las filas de las FARC se hizo notoria a partir de la mitad de la segunda década del noventa, cuando entidades de defensa de derechos humanos tanto nacionales como internacionales empiezan a informar y denunciar la presencia de esta población en este grupo. Al respecto Human Rights Watch (2.003) describió este fenómeno social de la siguiente manera:

"La incorporación de los niños a las filas de estos grupos es un fenómeno relativamente nuevo. En la década de los cincuenta, era posible que los niños acompañaran a las familias que habían escapado de los ataques y vivían en los campamentos de los rebeldes, pero era raro que combatieran. El medio universitario era un campo de reclutamiento muy favorable para algunos grupos 
guerrilleros mientras que otros buscaron adeptos entre los sindicalistas, campesinos $y$ desempleados adultos.

Esto cambió en los noventa, cuando la guerrilla y los paramilitares iniciaron sus grandes campañas de reclutamiento. En 1.996, la Defensoría del Pueblo publicó uno de los primeros informes que relataban este acontecimiento. En el informe se concluyó que hasta el $30 \%$ de algunas unidades guerrilleras estaba compuesto por niños se cree que, en las milicias urbanas, la mayoría de los reclutas, el 85\% son menores de 18 años."

Otro hecho que trae consigo la violencia en el país para los NNA, además de desplazarlos, asesinarlos o desaparecerlos, son las violaciones sexuales; experiencias que dejan huellas físicas y emocionales negativas en las niñas, que les impide volver a confiar en los demás, que afectan su propia estima y les impide entablar una relación basada en el placer y el respeto; eso, sin tener en cuenta que existen numerosos casos de enfermedades sexuales y embarazos involuntarios (Defensoría del Pueblo, 2014, pág. 32).

Así las cosas, niños, niñas y adolescentes quedan desprotegidos, ya que han perdido sus padres, sus abuelos, sus familiares más cercanos, sus compañeros de juego; situación que se acentúa en mayor grado cuando la perdida es de la madre, entrando en una fase de desamparo, lo que ha conllevado que en muchos casos el NNA sea entregado a sus parientes o amigos, trayendo como consecuencia la desintegración del núcleo familiar, y la presencia de traumas de índole psicológico y emocional.

Por último, es importante referir que los grupos armados al margen de la Ley, en los últimos veinte años han reclutado alrededor de 13.000 menores de edad, es decir, niños, niñas y adolescentes, de los cuales hay numerosos niños indígenas y afroascendientes, la mayoría entre 10 a 13 años; dichos reclutamientos los han realizado en 25 de los 32 departamentos, es decir, en el $78 \%$ del país. Según lo establecido por la Defensoría del Pueblo los departamentos que han sido víctimas de mayor reclutamiento son: Meta, Putumayo, Tolima, Cauca, Guaviare, Norte de Santander, Nariño, Caquetá, Cundinamarca, Cesar, Antioquia, Arauca y Bolívar (Grupo de Memoria Histórico, 2015).

\subsection{Marco jurídico}

La Constitución Política de 1991 consagra la prevalencia de los derechos de los NNA, constituyéndose en un deber su protección integral, y con la corresponsabilidad entre el Estado, a la Sociedad y la Familia (artículos 44 y 45) para su garantía y efectividad (Cont. N. art. 13). 
La Constitución Política de 1991 en su art 44 garantiza el desarrollo armónico e integral del pleno de los derechos a los niños, niñas y adolescentes. Tratándose del delito de reclutamiento ilícito, esta protección especial es fundamental, ya que se trata de NNA que ostentan el carácter de víctimas, razón por la cual se deben garantizar mecanismos especiales que respondan a dicha condición y que no provoquen re victimización.

El mencionado art. 44 constituye el desarrollo normativo de los principios internacionales por lo cual es necesario referirse, tanto a la Convención sobre los derechos de los NNA y a sus protocolos facultativos, como a los principios de París, y en materia especifica de investigaciones judiciales, a la Resolución 2005/20 del Consejo Económico y Social de las Naciones Unidad sobre asuntos judiciales que involucren a NNA víctimas y testigos de delitos (Consejo Económico y social (Ecosoc), 2005).

Así es fundamental realizar una interpretación de la Constitución Política y demás normas internas pertinentes, de manera armónica y sistemática, respecto de las herramientas internacionales sobre derechos humanos de la niñez. Las normas internas de procedimiento penal disponen la prelación de los instrumentos internacionales sobre la normatividad interna, y contando con la existencia de elementos probatorios mediante los cuales se pueda establecer la responsabilidad por los delitos de reclutamiento ilícito, para atender al interés superior de las niñas y los niños resulta indispensable hacer una interpretación de las normas sobre pruebas, acogiendo herramientas como las contenidas en declaraciones y resoluciones de organismos del sistema internacional de protección de los derechos humanos. Unos ejemplos de la aplicación extensiva de herramientas internacionales de protección de los derechos fundamentales se encuentran en la utilización de los principios rectores de los Desplazamientos internos, como lo expresa la Corte Constitucional en Sentencia T-025 DE 2004. (Colombia, Corte Constitucional (2004), Sentencia T-025, M.P. Manuel José Cepeda).

La Convención sobre los Derechos del Niño es el tratado del sistema universal de derechos humanos más importante en cuanto a reconocimiento y garantía de los derechos de la niñez; ella logró reunir y articular los derechos humanos de la infancia que estaban dispersos en otros instrumentos internacionales, los cuales posteriormente serían desarrollados de manera detallada en instrumentos especiales, tales como su Protocolo Facultativo relativo a la participación de niños en los conflictos armados, el Convenio 182 de la OIT y el Estatuto de Roma, de la Corte Penal Internacional, entre otros tratados en materia de niñez y conflicto armado.

La Corte Constitucional, a través de su sentencia C-203 de 2005 consideró a esta población como víctima del delito de reclutamiento ilícito, aunque tal condición no la exime de su responsabilidad Penal que llegase a imputárseles (Colombia, Corte Constitucional (2005), Sentencia C-203, M.P. Manuel José Cepeda), al recordar que 
la Ley 1098 de 2006 en su Artículo 169 establece que son sujeto de responsabilidad penal los adolescentes entre 14 y 17 años de edad. El Artículo 142, por su parte, señala quienes están excluidos de la misma.

En esta temática la jurisprudencia ha señalado que esta responsabilidad debe ser evaluada de forma individual, "con la debida atención a su corta edad, su nivel de desarrollo psicológico y su condición de víctima del delito de reclutamiento forzado, entre otro conjunto de factores que incluyen: (a) Las circunstancias específicas de la comisión del hecho; (b) las circunstancias personales y sociales del niño o adolescente implicado, entre ellas si ha sido, a su turno, víctima de un crimen de guerra; (c) El grado de responsabilidad que cabe atribuirles a los culpables del reclutamiento del niño y que impartieron las órdenes; (d) La responsabilidad de quienes, además de los reclutadores, han obrado como determinadores de su conducta (...)” (Coalición contra la vinculación de niños, niñas y jóvenes al conflicto armado en Colombia y Comisión Colombiana de Juristas, 2009, p. 48)

En la Sentencia C-240 de 2009, que declaró exequible los artículos 14 de la ley 418 de 1997 y 162 del Código Penal, la Corte Constitucional se pronunció señalando que la utilización de NNA en acciones de los grupos armados al margen de la ley configura un delito a la luz de las normas internacionales (Colombia, Corte Constitucional, (2009) Sentencia C-240, M.P. Mauricio González Cuervo).

En este orden de ideas, la Corte Constitucional mediante Auto 171 de 2001 señaló que esta entidad no ha sido informada sobre los procesos adelantados para la investigación del delito de reclutamiento ilícito, ni de los programas de atención para las víctimas de este delito realizados por parte del gobierno nacional; sumado a lo anterior, en Auto 215 de 2008 identifico como riesgo la situación de los derechos de los niños, niñas y adolescentes victimas de desplazamiento forzado, por ser un fuente de empleo y reclutamiento por parte de los actores armados organizados al margen de la ley.

De la misma forma, este delito es reconocido por la legislación nacional y esta descrita en el Código Penal ( Ley 599 de 2000), Ley de Seguridad Ciudadana ( Ley 1453 de 2011), Ley de Victimas ( ley 1448 de 2011), ley 1098 de 2006 (Código de Infancia y Adolescencia) y en las obligaciones internacionales establecidas en el marco jurídico Colombiano a través de la ratificación de los tratados internacionales; adicionalmente se consideró necesario la aplicación de las medidas utilizadas por el Estado en promover la adopción de los planes y rutas mediante actos administrativos, como decretos, acuerdos y ordenanzas en Prevención Temprana, Prevención urgente y de protección.

Teniendo en cuenta el mencionado bloque de constitucionalidad el gobierno nacional a partir del CONPES 3673 de 2010 estableció unos objetivos de política que buscan "Prevenir el reclutamiento y utilización de niños, niñas y adolescentes- NNA 
por parte de grupos armados organizados al margen de la ley y de grupos delictivos organizados, garantizando la prevalencia y goce efectivo de los derechos y la protección integral por parte de las familias, la sociedad y el Estado". Estos instrumentos se refieren a la priorización de la actuación institucional como principio de acción y de impulso a casos como mecanismo para garantizar la prevención.

No obstante observando los avances del Estado y la sociedad colombiana para reducir situaciones de vulnerabilidad y erradicar riegos que facilitan el reclutamiento y utilización de niños, niñas del territorio nacional, dada complejidad de esta situación, no es factible precisar cuántos NNA estarían en riesgo de ser reclutados y utilizados.

La Defensoría del Pueblo estima que son 8.000 los niños vinculados a grupos armados, Human Rights Watch señala que son 11.000 y la Fundación Maya Nassa que son 14.000, entre otros estimativos. Este amplio margen no permite con exactitud precisar la magnitud del reclutamiento y utilización de niños; aunque un sólo caso debe ser motivo de preocupación y movilización estatal y social, como lo refiere el documento Conpes 3673 de 2010.

\section{METODOLOGIA DE LA INVESTIGACIÓN}

El tipo de investigación desarrollado en el presente trabajo es de aproximación descriptiva, por cuanto se pretende identificar cual es la política pública en materia de prevención del reclutamiento forzado de NNA en los planes de gobierno de los municipios de Calamar, Miraflores y el Retorno del Departamento de Guaviare, y en particular si en los planes locales cuentan con capítulos referentes a la prevención del reclutamiento ilícito de NNA, durante el periodo de 2012 a 2016.

La técnica empleada es de tipo documental, haciendo uso del método hermenéutico, que tiene como propósito investigar, examinar y observar el significado y el sentido de las normas jurídicas; conocer los principios elaborados doctrinaria y jurisprudencialmente para efectuar una adecuada interpretación de la normatividad, la jurisprudencia y la doctrina.

\subsection{Diseño metodológico.}

Para la consecución tanto del objetivo principal como de los objetivos secundarios planteados en el presente trabajo, se ha diseñado una metodología estructurada en torno a los siguientes ejes:

Esta etapa corresponde al trabajo de elaboración del marco formal y teórico de la 
investigación, la que no implica en general, el desarrollo de un trabajo de campo y contacto con el terreno de investigación.

Las tareas que implican esta fase son las siguientes:

a) El análisis bibliográfico y el estudio documental, mediante una compilación de los estudios actualmente disponibles y que se expresa en dos tipos de trabajos de búsqueda, a saber, el análisis bibliográfico que tiene por objeto fundar la investigación en la tradición existente de investigaciones científicas sustentables y relativas al mismo tema y que significa hacer una recensión lo más completa y actualizada posible de los materiales publicados y su análisis y confrontación con el objeto de investigación. A su vez, el estudio documental tiene por objeto aportar todos los antecedentes estadísticos y cualitativos sustentables, pertinentes y actualizados, que estén en relación con la realidad del objeto de investigación y con la población o casos.

b) El marco conceptual y teórico, entendiendo por tal al corpus de conceptos, doctrinas, teorías atingentes y relacionadas con el objeto de investigación y que dé cuenta de cada uno de los objetivos, hipótesis y variables que se van a investigar. Este marco teórico se construirá según si el objeto de investigación responde a hipótesis que se deducen de datos provenientes de la experiencia o de resultados empíricos validados metodológicamente; o de teorías destinadas a validar hipótesis que han sido deducidas de una construcción teórica.

\subsection{Fuentes de investigación}

Respecto al tema objeto de la presente investigación, son consideradas como fuentes primarias de investigación:

\subsubsection{Primarias}

-Decretos, resoluciones, leyes, constituciones y demás normas dentro del ordenamiento jurídico nacional y demás normas de derecho comparado relacionadas con la materia.

-Jurisprudencia del Consejo de Estado, la Corte Constitucional y la Corte Suprema de Justicia.

-Declaraciones, convenios, conferencias, protocolos y demás documentos de carácter internacional que regulan la materia. 
-Textos jurídicos que señalan la doctrina especializada referida al tema.

-Doctrina nacional.

-Artículos de investigación.

-Documentos públicos.

\subsubsection{Secundarios}

Además de las fuentes formales del derecho, otro tipo de fuentes de importancia para desarrollar el contenido temático son:

-Revistas jurídicas especializadas.

-Textos jurídicos que señalan la doctrina especializada referida al tema.

-Enlaces de Internet especializados con la temática.

\section{RESULTADOS}

\subsection{Reclutamiento ilícito de NNA por grupos al margen de la ley en Colombia}

La doctrina de la protección integral de los niños, niñas y adolescentes fue acogida en Colombia a través de su regulación constitucional en los artículos 42, 43, 44 y 45 de la Carta Magna por causa de los compromisos adquiridos por el gobierno nacional al ser ratificada la Convención sobre los Derechos del Niño de 1989 mediante la ley 12 de 1992 expedida por el Congreso de la República.

Esta doctrina es entendida como un sistema general de principios y garantías que se aplican a los niños, niñas y adolescentes sin tener en cuenta su religión, raza, género, color, estrato social, etc, por cuanto en el derecho moderno son considerados como personas con un grado de vulnerabilidad, los cuales requieren unas condiciones especiales para su crecimiento y formación, cuyo propósito es garantizar el desarrollo de su personalidad al máximo grado (Colombia, Corte Constitucional, (2001), Sentencia T-979, M.P. Jaime Córdoba Triviño J., Bogotá).

Las garantías constitucionales más conocidas son el principio de la dignidad humana, el derecho a la vida, a la integridad física, a la salud, la seguridad social, al nombre, a la educación, a la familia, la nacionalidad, etc., los cuales por sus características especiales se constituyeron en derechos fundamentales y prevalentes. Con relación a la fundamentalidad de los derechos de las niñas y los niños, se resaltan entre otras las sentencias T-402/92 (M.P. Eduardo Cifuentes Muñoz) y SU-043/95 


\section{(M.P: Fabio Morón Díaz).}

Este es el motivo por el cual la Constitución Política estableció la obligación de asistir y proteger a los niños, niñas y adolescentes para garantizar su desarrollo armónico e integral y el ejercicio pleno de sus derechos (Colombia, Corte Constitucional, (2003), Sentencia C-273, M.P. Dra. Vargas Hernández C., Bogotá).

Por tal motivo, ha emergido diversidad de jurisprudencia emitida por la Corte Constitucional que ha desarrollado este principio. En la sentencia T-572 de 2010, la Corte sostuvo:

"Así, de acuerdo con lo establecido en el preámbulo de la Convención sobre los Derechos del Niño y en la Declaración de las Naciones Unidas sobre los Derechos del Niño y el artículo 44 de la Constitución Política, los derechos de los niños prevalecen sobre los derechos de los demás. A partir de esta cláusula de prevalencia, la jurisprudencia constitucional ha reconocido que los niños, niñas o adolescentes tienen un estatus de sujetos de protección constitucional reforzada, lo que significa que la satisfacción de sus derechos e intereses, debe constituir el objetivo primario de toda actuación (oficial o privada) que les concierna. Esta protección especial de la niñez y preservación del interés superior para asegurar el desarrollo integral se encuentra consagrada en diversos tratados e instrumentos internacionales que obligan a Colombia" (Colombia, Corte Constitucional, (2010), Sentencia T-572, M. P. Henao Pérez J., Bogotá).

Por otro lado, esta alta corporación considera que las razones de la especial protección constitucional de los NNA son:

“i) El respeto de la dignidad humana que, conforme a lo previsto en el Art. $1^{\text {o }}$ de la Constitución, constituye uno de los fundamentos del Estado Social de Derecho colombiano; ii) su indefensión o vulnerabilidad, por causa del proceso de desarrollo de sus facultades y atributos personales, en su necesaria relación con el entorno, tanto natural como social, y, iii) el imperativo de asegurar un futuro promisorio para la comunidad, mediante la garantía de la vida, la integridad personal, la salud, la educación y el bienestar de los mismos". (Colombia, Corte Constitucional, (2003), Sentencia C- 318, M. P. Araujo Rentería J., Bogotá).

Conforme lo expuesto, ante la situación particular que ha padecido Colombia en materia de conflicto armado interno, en el que de manera directa e indirecta la población de los NNA han participado, lleva a preguntar si las políticas públicas durante los últimos cinco años han permitido que se dé cumplimiento a la obligación del Estado de asistir y proteger a los niños(as) y adolescentes que han sido reclutados por diferentes grupos al margen de la ley, especialmente en materia de prevención de manera específica en los Municipios de Calamar, el Retorno y Miraflores del 
departamento de Guaviare.

Previo a dilucidar este cuestionamiento, el cual es el fundamento de la presente investigación, primero hay que comprender el fenómeno social del reclutamiento forzado de niños, niñas y adolescentes, por el impacto que ha tenido en diversidad de países que han soportado el flagelo de los conflictos armados en diferentes etapas históricas, donde las poblaciones más vulnerables (mujeres, adultos mayores, discapacitados y menores de edad) son los que han sido directamente los más afectados.

\subsubsection{El reclutamiento forzado de niños, niñas y adolescentes.}

La palabra reclutar es un verbo transitivo de origen francés proveniente de la expresión recruter, derivado de recrue 'recluta', participio del verbo recroître 'volver a crecer'. Inicialmente fue un término de la silvicultura que se aplicó al léxico militar. Posee dos acepciones, por un lado, significa reunir a un grupo de gente para una actividad o un fin determinado, y por otro, reunir y alistar gente para el ejército, para una campaña militar o para la guerra. (Diccionario Virtual, 2017)

A pesar de existir un concepto gramatical de la palabra reclutamiento tanto a nivel nacional e internacional, se observa una tendencia a creer que no existe una definición concreta, generalizada y aceptada del reclutamiento forzado de NNA, ante las muchas fuentes que tratan esta temática en las cuales utilizan variedad de terminología como: reclutamiento ilegal, reclutamiento ilícito o reclutamiento forzado, dando entender que tienen el mismo contexto.

A nivel doctrinal se vislumbran algunos intentos para definirla, de los cuales se resaltan los siguientes:

"el reclutamiento forzado es la vinculación permanente o transitoria de personas menores de 18 años de edad a grupos armados organizados al margen de la ley y/o grupos delictivos organizados que se lleva a cabo por la fuerza, por engaño o debido a condiciones personales o del contexto que la favorecen” (USAID, pág. 1).

Internacionalmente, ante la cruda realidad del reclutamiento forzado de NNA de 18 años, emerge el concepto del niño soldado, el cual, según los Principios de Ciudad del Cabo (1997), es toda persona menor de 18 años de edad que forma parte de cualquier fuerza armada regular o irregular en la capacidad que sea, lo que comprende, entre otros, cocineros, porteadores, mensajeros o cualquiera que acompañe a dichos grupos, salvo los familiares. La definición incluye a las niñas reclutadas con fines sexuales y para matrimonios forzados. Por consiguiente, no se refiere sólo a un niño o niña que lleva o ha llevado armas, sino también a los 
que prestan servicios de otro tipo para los grupos armados, aunque no participen directamente en el combate (UNICEF, 2014)-

Como complemento de lo anterior, los Principios de Paris, establece el concepto de niño soldado como: "todo menor de 18 años de edad vinculado con una fuerza armada o un grupo armado que haya sido reclutado o utilizado por una fuerza armada o un grupo armado en cualquier capacidad, incluidos los niños, tanto niños como niñas, aunque sin limitarse a ellos, utilizados como combatientes, cocineros, cargadores, espías o para fines sexuales”. (ONU, 2007).

Estos principios relativos a la situación de las instituciones nacionales, en su contenido, concretamente en los numerales 2.4 y 2.5 , establecieron los conceptos de reclutamiento y reclutamiento o utilización ilegal, el cual puede ser considerado como el primer concepto dentro del ámbito del Derecho Internacional Humanitario. Este documento expresa lo siguiente:

-Reclutamiento: Se refiere a conscripción o alistamiento obligatorio, forzado o voluntario de niños, niñas a cualquier tipo de grupo o fuerza armada.

-Reclutamiento o utilización ilegal: Es el reclutamiento o utilización de niños, niñas que están por debajo de la edad estipulada en los tratados internacionales aplicables a las fuerzas o grupos armados en cuestión o dentro de las normas nacionales aplicables (Oficina del Alto Comisionado de las Naciones Unidas para los Derechos Humanos, Módulo Los Derechos Económicos, Sociales y Culturales, Nueva York, Ginebra, pág. 33).

La jurisprudencia nacional emitida por la Corte Constitucional, ha referido que "el reclutamiento forzado de NNA de edad- niños, niñas y adolescentes- es una práctica criminal en la que incurren en forma extensiva, sistemática y habitual los grupos armados ilegales que toman parte del conflicto armado en Colombia" (Colombia, Corte Constitucional, (2008), Auto No. 251, M.P. Manuel José Cepeda Espinosa).

Conforme lo anteriormente expuesto, el reclutamiento y utilización de los NNA en el conflicto armado, es una clara violación de los derechos humanos, una infracción del derecho internacional humanitario y un delito internacional.

El antecedente de estas disposiciones son los llamados Principios de la Ciudad del Cabo sobre la prevención del reclutamiento de niños en las fuerzas armadas y desmovilización y reintegración social de los niños soldados en África, aprobados por los participantes en el simposio sobre prevención del reclutamiento de niños en las fuerzas armadas y desmovilización y reintegración social de los niños soldados en África, organizado por el UNICEF en cooperación con el subgrupo de organizaciones no gubernamentales del Grupo de Trabajo de Organizaciones no Gubernamentales para la Convención de los Derechos del Niño, Ciudad del Cabo, 30 de abril de 1997. 
En ellos se concibieron el reclutamiento obligatorio, forzado o voluntario en cualquier tipo de fuerza armada o grupo armado regular o irregular (Hernández R, 2014).

El Protocolo Facultativo sobre la participación de los niños en los conflictos armados, considera como conducta objeto de reproche el reclutamiento y utilización de menores de 18 años en las hostilidades, por parte de los grupos armados irregulares y el reclutamiento y participación directa en las hostilidades, de menores de 18 años por parte de las fuerzas armadas de los Estados.

El artículo 3 del mencionado instrumento internacional, aumentó la edad mínima para la participación directa en cualquier tipo de hostilidades desde los 15 años hasta los 18 años. Inicialmente, en el Protocolo I -Protocolo Adicional a las Convenciones de Ginebra de 1949- y en la Convención sobre los Derechos del Niño se establecían los 15 años como la edad mínima para la participación directa en las hostilidades. El Protocolo II de la Convención de Ginebra estableció también los 15 años como edad mínima, pero no distinguía entre la participación directa o indirecta (UNICEF, 2004, pág. 13).

Por otro lado, el artículo 4 estableció la prohibición a los grupos armados distintos de las fuerzas armadas de un Estado para que en ninguna circunstancia recluten o utilicen en hostilidades a menores de 18 años.

Los Estados Partes igualmente están obligados a adoptar todas las medidas posibles para impedir ese reclutamiento y utilización, con inclusión de la adopción de las medidas legales necesarias para prohibir y tipificar esas prácticas.

El Convenio 182 sobre la prohibición de las peores formas de trabajo infantil y la acción inmediata para su eliminación, considera que el reclutamiento forzoso u obligatorio de niños para utilizarlos en conflictos armados y la utilización, y el reclutamiento o la oferta de niños para la realización de actividades ilícitas, en particular la producción y el tráfico de estupefacientes, tal como se definen en los tratados internacionales pertinentes son actos que atentan con los derechos de los NNA (OIT, Convenio 182 sobre la Prohibición de las peores formas de trabajo infantil y la acción inmediata para su eliminación, artículo 3 ordinales a y c).

Para el Derecho Penal Internacional, es considerada como conducta punible y crimen de guerra, el reclutar o alistar niños menores de 15 años en las fuerzas armadas o utilizarlos para participar activamente en hostilidades, tanto si se trata de fuerzas armadas o de grupos armados irregulares (Naciones Unidas, Estatuto de Roma, art. 8 num. 2 ord. xxvi).

El objetivo de las disposiciones internacionales es asegurar que la persona menor de 18 años no forme parte de cualquier fuerza o grupo armado regular o irregular, porte o no porte armas, sin importar si su vinculación ha sido forzada o 
voluntaria, por cuanto el concepto de "niño soldado" es amplio (Colombia, Corte Constitucional, (2009), Sentencia C-240, González Cuervo M. Bogotá).

Dentro del marco legal colombiano para la protección de los niños y las niñas que participan en el conflicto armado, el artículo $\underline{20}$ del Código de la Infancia y de la Adolescencia aseguró como Derechos de Protección de los NNA contra: "el reclutamiento y la utilización de los niños por parte de los grupos armados organizados al margen de la ley" (Congreso de la República, ley 1098 de 2006, art. 20).

A su vez el artículo $\underline{41}$ sobre "Obligaciones del Estado", reconoce que el:

"Estado es el contexto institucional en el desarrollo integral de los niños, las niñas y los adolescentes. En cumplimiento de sus funciones en los niveles nacional, departamental, distrital y municipal deberá: (...) 6. Investigar y sancionar severamente los delitos en los cuales los niños, las niñas y las adolescentes son víctimas, y garantizar la reparación del daño y el restablecimiento de sus derechos vulnerados". Además, entre esas obligaciones, está la de "protegerlos contra la vinculación y el reclutamiento en grupos armados al margen de la ley" (Congreso de la República, ley 1098 de 2006, art. 41).

En cuanto a los Procedimientos Especiales cuando NNA son Víctimas de Delitos, el artículo 192 reconoce como Derechos Especiales de los Niños, que "el funcionario judicial tenga en cuenta los principios del interés superior del niño, prevalencia de sus derechos, protección integral y los derechos consagrados en los Convenios Internacionales ratificados por Colombia, en la Constitución Política y en esta ley" (Congreso de la República, ley 1098 de 2006, art. 192).

La Ley 418 de 1997 consagra en su artículo 17, que es deber del Instituto Colombiano de Bienestar Familiar- ICBF, diseñar y ejecutar un programa especial de protección para la asistencia de todos los casos de menores de edad que hayan tomado parte en las hostilidades o hayan sido víctimas de la violencia política, en el marco del conflicto armado interno. Igualmente prestará asistencia prioritaria a los menores de edad que hayan quedado sin familia o cuya familia no se encuentre en condiciones de cuidarlos (Congreso de la República, ley 418 de 1997, art. 17).

En lo que concierne a la acción punitiva del Estado y a la persecución de las conductas proscritas en contra de los NNA por reclutamiento y utilización de niños y niñas en el conflicto armado, el artículo 14 de la Ley 418 de 1997 establece que será sancionado con prisión de 3 a 5 años: quien reclute a menores de edad para integrar grupos insurgentes o grupos de autodefensa, los induzca a integrarlos, los admita en ellos o les de entrenamiento militar. En el caso colombiano como se ha dicho, se entiende por menores a los niños y niñas en edad inferior a los 18 años (Congreso de la Congreso, ley 418 de 1997, art. 14). 
La Ley $\underline{548}$ de 1999, consagró la prohibición de incorporación de menores de 18 años al servicio militar obligatorio, atendiendo entones las directrices internacionales (Congreso de la República, ley 548 de 1999).

Finalmente, el artículo $\underline{162}$ del Código Penal-, establece el tipo penal del reclutamiento ilícito. Por medio de esa disposición los adultos pertenecientes a grupos armados que recluten personas menores de 18 años y los obliguen a participar en las hostilidades bien en forma directa o indirecta, serán sujetos de la acción penal (Congreso de la República, ley 599 de 2000, art. 162).

Por otra parte, la Ley $\underline{782}$ de 2002 "Por medio de la cual se prorroga la vigencia de la Ley 418 de 1997, prorrogada y modificada por la Ley 548 de 1999 y se modifican algunas de sus disposiciones", otorga a los menores que participen en el conflicto armado, la condición de víctimas de la violencia política (Congreso de la República, ley 782 de 2002).

La Ley de Justicia y Paz definió que no se pueden otorgar beneficios jurídicos a aquellos grupos ilegales que hayan reclutado personas menores de 18 años y en cambio, tendrán beneficios adicionales si entregan a la protección del Estado, los niños, las niñas y adolescentes pertenecientes a sus filas, pero en la sentencia C- $\underline{370}$ de 2006, la Corte Constitucional precisó que el no confesar el delito de reclutamiento ilícito de personas menores de 18 años durante las versiones libres, y luego comprobarse que se ha faltado a la verdad, genera la pérdida de tales beneficios (Congreso de la República, ley 975 de 2005; Corte Constitucional, Sentencia C-370 de 2006, Magistrados Ponentes: Manuel José Cepeda Espinosa, Jaime Córdoba Triviño, Rodrigo Escobar Gil, Marco Gerardo Monroy Cabra, Álvaro Tafur Galvis, Clara Inés Vargas Hernández).

El Decreto $\underline{1290}$ de 2008 sobre Reparación Administrativa para las víctimas de la violencia de los grupos armados ilegales, se definió el delito de reclutamiento de menores de 18 años y se estipuló que los menores víctimas de este flagelo tendrían derecho a los beneficios del decreto, independientemente del proceso judicial en el que se asegure su derecho a la verdad y a la justicia (Congreso de la República, Decreto 1290 de 2008).

\subsubsection{Formas de reclutamiento}

Para la Corte Constitucional, el reclutamiento se realiza mediante la captación, que se entiende que todo niño, niña o joven es captado cuando es menor de 18 años y se vincula a participar en las acciones de guerra orientadas por un grupo armado irregular, con una motivación política, sean estas de inteligencia, logística o combate 
y ha sido capturado, se ha entregado voluntariamente o ha sido obligado por el grupo armado irregular.

Para el Protocolo Facultativo, la doctrina generalizada y la misma jurisprudencia de la Corte Constitucional, existen dos formas de reclutamiento: la voluntaria y la forzada.

-Reclutamiento Voluntario: Es cuando el menor se ve impulsado a ingresar a grupos armados regulares o irregulares entre otros por exceso de tiempo libre, abandono familiar, moral o físico, por carencias económicas son también facilitadoras de esta dinámica, particularmente en aquellas zonas agobiadas por el conflicto y con esquemas productivos deficientes producto del conflicto.

-Reclutamiento Forzado: Cuando el niño, la niña o el joven haya ingresado al grupo armado ilegal inicialmente por retención o coerción física (Colombia, Corte Constitucional, 2009 Sentencia C240, Mauricio González Cuervo M).

Además de las anteriores para el Ministerio de Defensa existen los siguientes:

-Reclutamiento Sugerido: Cuando los mismos padres llevan al niño al grupo armado ilegal tal como sucede en la franja de gaza que incorporan a su hijo a los grupos armados.

-Reclutamiento por cuotas: Es aquel por medio del cual una familia tiene que dar al menos uno de sus hijos al grupo armado ilegal, de tratarse de una familia con un solo hijo, pocos hombres o reducidas se han excepcionalmente excepciones a petición de los padres, si bien sus hijos no siempre comparten la voluntad de sus progenitores.

-Reclutamiento Obligatorio: Al ser el menor coaccionado por mecanismos diferentes al físico. (Ministerio de Defensa Nacional, 2012).

\subsubsection{Factores de vulnerabilidad y riesgo para el reclutamiento forzado de niños, niñas y adolescentes.}

El contexto de vulnerabilidad de Niños, Niñas, Adolescentes y Jóvenes, está asociado a factores intrínsecos de la comunidad o grupo que se encuentra en riesgo, frente al potencial del daño presente en la amenaza, pero también con la disposición o ausencia de medios de protección que descansan en la responsabilidad que tiene el Estado en pro de los habitantes del territorio nacional. Algunos de estos medios se asocian a capacidades sociales, mientras otros están relacionados con las condiciones de vida y ubicación relativa en la estructura social que exacerban la predisposición a sufrir el daño, tales como prestación de servicios públicos, saneamiento básico, salud, etc. 
No existe una unificación de los criterios o causas que generan el reclutamiento ilegal de los NNA por grupos al margen de la ley, ha sido diversos doctrinantes como entidades gubernamentales $\mathrm{Y}$ privadas, quienes a través de diversos estudios investigativos han tratado de identificar estos factores de riesgo tanto en el ámbito nacional como internacional.

Michael Wessells, al realizar un estudio en África subsahariana, en el que observó niños de todas las edades que fueron reclutados de forma voluntaria como forzada en conflictos armados, concluyó que los factores de riesgo que inciden en el reclutamiento de NNA se condensaban en dos grandes grupos: los riesgos de tipo macro social como la pobreza, opresión, ideología, conflicto armado y militarización, y los factores de riesgos de tipo micro social como la familia, la escuela y la comunidad. (Wessells,2002, pp. 249-252).

La Defensoría del Pueblo a través del informe defensorial de caracterización de los niños, niñas y adolescentes identificó circunstancias de diversa índole, que facilitaron y produjeron el reclutamiento e ingreso del NNA a grupos armados, dentro de las cuales deben considerarse, antecedentes de violencia intrafamiliar, violencia sexual, trabajo infantil, y la precaria presencia del Estado a través de sus instituciones en algunas regiones del país. Los factores de riesgo fueron clasificados en los siguientes grupos: riegos individuales, riesgos familiares, riesgos sociales, riesgos estatales y riesgo asociados al conflicto directamente.

Tabla No. 1

\begin{tabular}{|c|c|}
\hline Clase de Factor & Identificación de factores \\
\hline $\begin{array}{l}\text { Factores de Riesgo } \\
\text { Individuales }\end{array}$ & $\begin{array}{l}\text { - Necesidad de protección y/o reconocimiento: cuando el } \\
\text { entorno familiar no ofrece cuidado alguno o por el } \\
\text { contrario, genera violencia. } \\
\text { - Desconocimiento, ignorancia o falta de información, que } \\
\text { conlleva a que el NNA asuma como normales y legales } \\
\text { ciertos actos de violencia en contra suya. } \\
\text { - Presencia de imaginarios soportados en la búsqueda de } \\
\text { poder y riqueza a través del uso de las armas o el desarrollo } \\
\text { de actividades ilegales. } \\
\text { - Expulsión temprana del hogar. } \\
\text { - Violencia sexual. }\end{array}$ \\
\hline $\begin{array}{l}\text { Factores de riesgo } \\
\text { Familiares }\end{array}$ & $\begin{array}{l}\text { - Antecedentes de violencia intrafamiliar. } \\
\text { - Antecedentes de violencia sexual. } \\
\text { - Trabajo Infantil. } \\
\text { - Pertenencia de algún miembro de la familia a un grupo } \\
\text { armado ilegal. }\end{array}$ \\
\hline
\end{tabular}




\begin{tabular}{|c|c|}
\hline $\begin{array}{l}\text { Factores de riesgo } \\
\text { sociales }\end{array}$ & $\begin{array}{l}\text { - Ausencia de redes u organizaciones de protección } \\
\text { institucional o comunitaria. } \\
\text { - Ausencia de redes de apoyo productivo para las familias } \\
\text { de los NNA víctimas (desempleo, pobreza extrema y falta } \\
\text { de oportunidades). }\end{array}$ \\
\hline $\begin{array}{lll}\text { Factores de riesgo } \\
\text { estatales }\end{array}$ & $\begin{array}{l}\text { - Insuficiente cobertura de oferta en educación y/o baja } \\
\text { calidad o falta de docentes. } \\
\text { - Inoperancia de las autoridades locales/municipales por } \\
\text { desconocimiento y/o miedo. } \\
\text { - Ausencia de autoridades en lo local y lo municipal con } \\
\text { capacidad de atención a NNA víctimas o en riesgo o para el } \\
\text { desarrollo de estrategias de prevención del reclutamiento y } \\
\text { la utilización. } \\
\text { - Necesidades básicas insatisfechas y ausencia o falta de } \\
\text { cobertura de servicios públicos esenciales. }\end{array}$ \\
\hline $\begin{array}{l}\text { Factores de riesgo } \\
\text { asociados al conflicto } \\
\text { directamente }\end{array}$ & $\begin{array}{l}\text { - Presencia de actores armados ilegales (pueden o no tener } \\
\text { control territorial de la zona). } \\
\text { - Desarrollo de actividades económicas ilícitas (cultivos } \\
\text { ilícitos, minería ilegal o artesanal, contrabando, etc.). } \\
\text { - Desplazamiento forzado. }\end{array}$ \\
\hline
\end{tabular}

Fuente: Defensoría del Pueblo, Unicef- 2006

Por otro lado, las situaciones que aumentan el riesgo de reclutamiento y de utilización de la población menor de 18 años, de acuerdo con la Secretaria Técnica de la Comisión Intersectorial, son: i) presencia o tránsito de grupos organizados al margen de la ley y de grupos delictivos organizados; ii) presencia de economías y actividades ilegales (narcotráfico, micro-tráfico, contrabando, redes de trata o tráficos de armas, por ejemplo) y zonas de tránsito de las actividades ilegales; iii) altos índices de violencia sexual e intrafamiliar contra niños y niñas; iv) altos índices de homicidio; v) presencia de minas antipersonales; vi) regiones por bajos índices económicos y de marginalidad social e vii) Informes de Riesgos o Alertas del SAT, verificados por el CIAT (Consejo Nacional de Política Económica y Social República de Colombia Departamento Nacional de Planeación, COMPES 3673, Pág. 61) .

El Programa de Naciones Unidas para el Desarrollo, PNUD, a partir de diferentes fuentes, visibiliza cinco (5) factores de riesgos de reclutamiento y 
utilización de niños, niñas y adolescentes. Estos son: i) vivir en zonas de violencia; ii) idealizar lo armado; iii) vivir en un entorno familiar disfuncional, iv) la pobreza y los niños trabajadores y v) el desplazamiento y la disputa de riquezas (Naciones Unidas (2008), Hechos del Callejón, No. 38, Año 4, Bogotá).

\subsubsection{Mecanismos para el reclutamiento y la utilización de NNA por los grupos ilegales en Colombia.}

Para el caso colombiano, los diferentes actores que desempeñan un rol activo en materia de reclutamiento ilegal de NNA, han utilizado muchos métodos para lograr tal acometido con fundamento en la incidencia de los factores de riesgos que convergen para cada situación en particular. Como ya es reiterativo, este fenómeno ha sido objeto de diferentes estudios de los cuales se extraen los que se han considerado como relevantes o principales.

La Corte Constitucional en su jurisprudencia ha considerado que el reclutamiento forzado de menores de edad se efectúa mediante el uso directo de violencia, el secuestro, la abducción, o la intimidación directa a los niños y/o sus familias; otros ingresan a estos grupos para defenderse a sí mismos o a sus familiares. Por lo general, las víctimas del reclutamiento forzoso provienen de sectores sociales pobres, analfabetas y rurales, (Corte Constitucional, Sentencia C-203/05, M.P. Manuel José Cepeda Espinosa).

La Defensoría del Pueblo en un informe realizado para el año 2012, copiló los siguientes métodos de reclutamiento:

- Uso de los NNA en zonas rurales y urbanas en actividades de inteligencia o colaboración permanente con el grupo armado, sin que exista el rompimiento con el núcleo familiar o del sistema educativo al que el niño o niña pertenece.

- Reclutamiento a través de distintos actos de seducción, engaño o convencimiento, encaminados a que niños, niñas y adolescentes realicen actividades específicas y permanentes, relacionadas con formas de explotación sexual o económica.

- Utilización a través de distintos actos de seducción (ofrecimiento de dinero, de una vida mejor, de oportunidades educativas, de oportunidades laborales, entre otras), para que niños, niñas y adolescentes realicen actividades esporádicas para los grupos armados.

- Utilización a través de distintos actos de seducción o de explotación económica (ofrecimiento de dinero, por ejemplo), para que niños, niñas y adolescentes realicen actividades económicas específicas para los grupos, sin que éstas sean necesariamente a priori negocios ilícitos. 
- Utilización a través de distintos actos de engaños en los que el niño, niña o adolescente no sabe que está siendo utilizado por el grupo armado ilegal. Ejemplo: niño al que una persona vestida de civil le entrega un paquete bomba. (Defensoría del Pueblo, 2012).

Para Nathalia Springuer, en el documento denominado "Como corderos entre lobos" (2012), manifiesta que el reclutamiento es un proceso gradual, metódico y selectivo. De la información dada por esta autora, se presentan las siguientes modalidades de reclutamiento:

-Realización previa de actos de milicia y tareas en favor de grupos al margen de la ley.

-La utilización de la creencia de la población que los miembros de grupos armados ilegales no son una amenaza al orden y convivencia ciudadana sino miembros habituales de la comunidad.

-Aprovechamiento en algunos de municipios de situación reducida de tasa de necesidades básicas insatisfechas (NBI), como la falta de servicios educativos, de salud y servicios públicos domiciliarios, junto con la desinstitucionalización.

-El uso de lazos familiares o de personas conocidas para su vinculación.

-Manipulación de las ideas de venganza.

-Oferta de opciones laborales.

En documento emitido por Human Rights Wath en el 2003, también fueron considerados el reclutamiento voluntario, la organización de campañas de reclutamiento, oferta de promesas de dinero y un futuro prometedor, como forma de escape a las víctimas de violencia familiar y abuso físico y sexual, la promesa de aventuras, camaradería y oportunidad de demostrar valía, y la seducción para el logro de poder que da las armas (Human Rights Wath, 2003, Pág.28).

Por otra parte, también son considerados como métodos de vinculación la irrupción en las escuelas, las amenazas permanentes, las promesas de condiciones mínimas de subsistencia (Coalición contra la vinculación de NNA al conflicto armado en Colombia- Comisión Colombiana de Juristas, 2009).

\subsubsection{Grupos en que son reclutados los NNA en Colombia.}

Para la Corte Constitucional, es un hecho comprobado que el reclutamiento ilícito de NNA de edad -niños, niñas y adolescentes- es una práctica criminal en la 
que incurren en forma extensiva, sistemática y habitual los grupos armados ilegales que toman parte del conflicto armado en Colombia. Según estudios realizados por la Defensoría del Pueblo en relación con menores desmovilizados, los grupos armados ilegales de los que procedían la mayoría de los niños, niñas y adolescentes desvinculados eran: las Fuerzas Armadas Revolucionarias de Colombia - FARC, seguido de las Autodefensas Unidas de Colombia - AUC, el Ejército de Liberación Nacional - ELN, las Autodefensas Campesinas del Casanare - ACC, el Ejército Revolucionario del Pueblo - ERP, y otra serie de organizaciones como el Ejército Popular de Liberación - EPL y el Jorge Eliécer Gaitán (JEGAS); así como de otros grupos de autodefensas como las Autodefensas Campesinas del Magdalena Medio (ACMM). Dentro de las Autodefensas Unidas de Colombia AUC, se agruparon el Bloque Central Bolívar - BCB, las Autodefensas Campesinas de Córdoba y Urabá ACCU, y las Autodefensas Unidas del Centro del Cesar -AUCC, (Corte Constitucional, Auto N 251 de 2008 M. P. Manuel José Cepeda Espinosa).

La Unidad de Justicia y Paz de la Fiscalía General de la Nación, afirma que la guerrilla de las FARC- EP desarrolló esta práctica en 31 departamentos del país, pues el único lugar que no existe reportes o denuncias de este delito es San Andrés y Providencia (El Espectador, 2013).

El Instituto Colombiano de Bienestar Familiar (ICBF), entidad encargada de recibir a los menores de edad que combatieron en la guerra, ha señalado que entre 1999 y enero de 2015, esta entidad ha atendido a 5.708 menores provenientes de guerrillas, paramilitares y bandas criminales. Conforme a la información de niños y adolescentes que pertenecían a estos grupos, se considera que la Farc aparece como el mayor reclutador en los registros históricos del ICBF con cerca del 60\% de los niños atendidos, seguidos por las Auc con el 20\%, el Eln con $15 \%$ y Bacrim con poco menos del 5\%. Por su parte la Unidad para la Atención de Víctimas tiene registros de 7.722 menores de edad víctimas reclutamiento entre 1985 y el 1 de noviembre de 2014 (Verdadabierta.com, 2015).

Entre enero 2009 y agosto de 2011, las FARC-EP reclutaron y amenazaron con reclutar o utilizar a NNA a 121 municipios en 22 departamentos en la región de las costas del Caribe y Pacífico, las zonas fronterizas y el centro del país. El ELN, se ha conocido de casos en 55 municipios de 8 departamentos a lo largo de la frontera venezolana en los departamentos de las dos costas (ONU, 2012, Op. Cit. Párrafo 16).

En la actualidad gracias al proceso de desmovilización de los grupos paramilitares fueron entregados de manera unilateral y colectiva al ICBF un número aproximado de de 800 NNA (Coalico, 2011). No obstante, se ha suscitado debate en cuanto al reclutamiento de niños por grupos denominados por el gobierno como Bacrim. Igualmente, a partir de las negociaciones de paz entre el gobierno y las FARC-EP en la Habana y gracias al cese de hostilidades entidades como el ICBF y el Ministerio de Defensa (2016) han verificado el cese de esta pràctica por este grupo armado. No obstante, persiste el reclutamiento por miembros del ELN. 
A nivel estadístico, sólo hasta el mes de agosto de 2018 en el Informe denominado "Una guerra sin edad" elaborado por CNMH, develó a nivel nacional cifras consolidadas en materia de reclutamiento de NNA entre el período de tiempo comprendido de 1958 -2015. De este informe se resalta como datos importantes los siguientes: A. Todos los grupos armados al margen de la ley han reclutado de manera ilícita a NNA. B. La CNMH tiene 16.789 registros sobre el reclutamiento y utilización de NNA en el conflicto armado en Colombia. C. De la anterior cifra, solo en un $62 \%$ el informe pudo discriminar que actor armado reclutó a los menores. D. Las guerrillas han sido los mayores reclutadores de menores con un $69 \%$ del total de la muestra (8.701 casos). E. Los porcentajes de reclutamiento de cada actor armado son: la FACR un 54\%, los paramilitares un $27 \%$, el ELN un $10 \%$, grupos armados post desmovilización en un $7 \%$, el ejército revolucionario guevarista $1 \%$ y el ejército revolucionario del pueblo en un $1 \%$.

Igualmente, las veinte regiones donde se ha dado mayor reclutamiento de NNA entre 1960 y 2016 son: Ariari Guayabero, magdalena medio, Florencia y área de influencia, Urabá, Cagúan, Andén del Pacífico Sur, Sur del Tolima, Sierra Nevada de Santa Marta, Piedemonte llanero, Altillanura, Eje Cafetero, Sarare, Valle de Aburra, Norte del Cauca, Alto Sinú y San Jorge, Bajo Cauca Antioqueño, Oriente Antioqueño, Bajo Putumayo, Amazonía Suroriental y Patía. Las zonas donde se ha reportado un mayor reclutamiento han sido históricamente son las que ha tenido mayor presencia y control de los actores armados.

El 71\% de los NNA reclutados son niños y adolescentes hombres con 12.030 registros de los 16.879 registros totales y el 29\% son mujeres (CNMH, 2018).

\subsubsection{Acciones ilegales específicas a las que son sometidos NNA víctimas de reclutamiento y utilización}

El reclutamiento ilícito de NNA por parte de grupos al margen de la ley, es un delito de lesa humanidad, y se produce como una violación flagrante de todos los mandatos, acuerdos y protocolos adoptados por Convenciones y Tratados Internacionales, la razón radica en que los niños y las niñas en los conflictos armados se encuentran protegidos por el DIH desde una doble perspectiva: (i) en su calidad de civiles afectados por las hostilidades y (ii) como sujetos vinculados a ellas en conflictos armados internacionales y no internacionales, de acuerdo con los artículo 77 del Protocolo I y al artículo $4^{\circ}$ del Protocolo II adicionales a los Convenios de Ginebra, respectivamente, siendo el reclutamiento y la participación de menores de 15 años de edad en los conflictos armados, una conducta prohibida por el DIH (Colombia, Corte Constitucional, (2009), Sentencia C240, M.P. González 


\section{Cuervo M.).}

El Comité de los Derechos del Niño ha expresado preocupación por la gravedad de la situación de la vinculación de la niñez al conflicto en Colombia, en especial por los siguientes motivos:

a) El reclutamiento en gran escala de niños por los grupos armados ilegales se encuentra motivado para el uso en combate y como esclavos sexuales. Así lo reconoce el Informe del Secretario General sobre los niños y el conflicto armado en Colombia, documento No. S/2012/171, 6 de marzo de 2012, párrafo 14. 3 (Corte Constitucional,2008, Auto 251. M.P. Manuel José Cepeda Espinosa).

b) El interrogatorio por las Fuerzas Armadas de los niños soldados capturados y desmovilizados y el incumplimiento del plazo máximo de 36 horas establecido en la legislación nacional para entregarlos a las autoridades civiles.

c) La utilización de niños por las Fuerzas Armadas para obtener información de inteligencia.

d) El nivel insuficiente de reintegración social, rehabilitación y reparación de que disponen los niños soldados desmovilizados- desvinculados, (Comité de los Derechos del Niño (2006).

Esta situación se torna más compleja, cuando se observa que los grupos al margen de la ley utilizan una amalgama de acciones ilegales específicas a las que son sometidos NNA las víctimas de reclutamiento, colocando en grave riesgo sus vidas y sus derechos fundamentales. Las principales actividades que realizan los NNA cuando son reclutados son:

- Actividades militares y/o de combate.

- Actividades de vigilancia, como informantes o campaneros.

- Actividades de apoyo logístico: cocina, lavado de ropa, etc.

- Tráfico o micro tráfico de sustancias ilícitas.

- Transporte de sustancias ilícitas o de apoyo para el grupo ilegal.

- Inducción al reclutamiento y utilización a otros NNA.

- Mensajería o transporte de suministros, armas o artefactos de cualquier índole.

- Extorsión. 
- Hurtos.

- Sicariato (Defensoría del Pueblo (2014).

\subsection{POLÍTICA PÚBLICA DE PREVENCIÓN DEL RECLUTAMIENTO ILICITO EN COLOMBIA}

\subsubsection{Concepto}

Antes de abordar el tema del presente capítulo, es necesario comprender de primera mano, el concepto de política pública para luego pasar a analizar la política pública sobre prevención del reclutamiento.

Diversos autores han expuesto variedad de definiciones, de las cuales resaltamos las siguientes:

Brum considerada que es un fenómeno social, administrativo y político específico, resultado de un proceso de sucesivas tomas de posición, que se concretan en un conjunto de decisiones, acciones u omisiones, asumidas fundamentalmente por los gobiernos, mismas que traducen, en un lugar y periodo determinado, la respuesta preponderantemente del mismo frente a los problemas públicos vividos por la sociedad civil (Porrúa, 2006).

Por su parte, Cano considera que se trata de un flujo de acciones y decisiones intencionalmente coherentes y racionalmente focalizadas a fin de resolver, de manera puntual, un problema definido como público. Este concepto contiene una pauta normativa de direccionamiento de la acción pública, como también un instrumento analítico de observación de tal gestión (Cano, 2010).

Los doctrinantes Betancourt y Ramírez (2008) la definen como un instrumento a partir del cual el Estado regula la vida social y demás a través de la promulgación de textos jurídicos y administrativos, de la creación de organizaciones y de otras formas concretas en las que se viabilizan las decisiones públicas. Además, señalan que los elementos que la integran son: i) principios: es la representación general sobre la manera de conducir los asuntos públicos, ii) objetivos: son prioridades específicas definidos en relación en relación con un asunto particular, iii) conjunto de medidas concretas: decisiones, acciones, disposiciones, procedimientos y instrumentos: medios disponibles para alcanzar los objetivos propuestos. Los investigadores Aguilar y Lima, al realizar un análisis de varias definiciones propuestas por doctrinantes de lo que es el concepto de política pública, han destacado que convergen ocho elementos constitutivos de las misma: a) Resolver problemas públicos acotados, b)las decisiones implican conflicto, c)e discute el problema, pero más aún, la manera de abordarlo, d)Participación de múltiples actores, e) un proceso, - f) no se desplaza al gobierno, sino que se legitima, g) la población afectada se involucra en la solución, h) es un 
ciclo y no una secuencia lineal.

Finalmente, Astorga y Lima (2009) consideran que la política pública enfrenta cuatro retos importantes a saber: i) Flexibilidad para adoptar cambios que logren objetivos y metas de la alternativa que hemos seleccionado como políticas, ii) Involucrar los niveles de la participación en los ciclos de política, iii)lograr que el diseño de política sea una realidad aplicable (pasar de la formulación a la implementación), evaluable y consensuada social y políticamente y iv) revertir el problema no administrarlo.

A partir de los conceptos expuestos se concluye que la política pública son las acciones del gobierno, con objetivos de interés público, que emergen de decisiones fundamentadas en un proceso e diagnóstico y análisis de factibilidad con la finalidad de atender problemas específicos de carácter público, con la participación de la ciudadanía en la definición de problemas y soluciones.

\subsubsection{Antecedentes del diseño de la política pública de prevención del reclutamiento ilícito de NNA.}

Muchas fuentes, investigaciones, informes realizados por diferentes entes públicos como privados coinciden en que la situación del reclutamiento ilícito en Colombia es grave y que se requieren políticas públicas claras dirigidas a su prevención y atención, ejemplos claros e importantes ha sido los trabajos realizados por la UNICEF, la Defensoría del Pueblo (Defensoría del Pueblo y UNICEF, La niñez en el conflicto armado interno, Diciembre 2002), el ICBF (Ministerio de Protección Social e ICBF, 2004), Human Rights Watc (op. Cit. P.6).

Adicionalmente, en estos documentos se señala que es necesario una comprensión del fenómeno del reclutamiento ilícito a partir de la concepción de los niños y niñas como sujetos de derechos, por lo que las estrategias para su protección y atención integral deben estar articuladas con la disposición de la Convención Internacional de los Derechos del Niño y la Constitución Política de 1991 (Ministerio de Educación, 2011, pág. 10). Esto significa que, las políticas públicas diseñadas para proteger a esta población deben estar acordes a los tratados internacionales ratificados por Colombia y deben propender por el abordaje de los niños y niñas víctimas de reclutamiento como sujetos de derecho.

Dentro de las disposiciones más relevantes que el Estado debe acatar gracias a la firma de tratados internacionales, y que sirven de base para el diseño de la política pública se resaltan las siguientes:

- - La Convención sobre los Derechos del Niño, que dispone en su 
artículo 3-1 que "en todas las medidas concernientes a los niños que tomen las instituciones públicas o privadas de bienestar social, los tribunales, las autoridades administrativas o los órganos legislativos, una consideración primordial a que se atenderá será el interés superior del niño"; y en el artículo 3-2, establece que "los Estados partes se comprometen a asegurar al niño la protección y el cuidado que sean necesarios para su bienestar, teniendo en cuenta los derechos y deberes de sus padres, tutores $u$ otras personas responsables de él ante la ley y, con ese fin, tomarán todas las medidas legislativas y administrativas adecuadas" (Este tratado fue ratificado por el Estado Colombiano mediante la ley

- $\quad$ El Pacto Internacional de Derechos Civiles y Políticos dispone en su artículo 24-1 que "todo niño tiene derecho, sin discriminación alguna por motivos de raza, color, sexo, idioma, religión, origen nacional o social, posición económica o nacimiento, a las medidas de protección que su condición de menor requiere, tanto por parte de su familia como de la sociedad y del Estado".

- El artículo 19 de la Convención Americana de Derechos Humanos, dispone que "todo niño tiene derecho a las medidas de protección que su condición de menor requiere por parte de su familia, de la sociedad y del Estado".

- El artículo 10-3 del Pacto Internacional de Derechos Económicos, Sociales y Culturales, ordena que "se deben adoptar medidas especiales de protección y asistencia a favor de todos los niños y adolescentes, sin discriminación alguna por razón de filiación o cualquier otra condición".

- $\quad$ El Principio 2 de la Declaración de las Naciones Unidas sobre los Derechos del Niño dispone que los niños gozarán de especial protección, y serán provistos de las oportunidades y recursos necesarios para desarrollarse física, mental, moral, espiritual y socialmente de manera normal y sana, y en condiciones de libertad y dignidad; para ello, precisa la Declaración, las autoridades tomarán en cuenta, al momento de adoptar las medidas pertinentes, el interés superior del menor como su principal criterio de orientación.

- Finalmente, el Protocolo Facultativo relativo a la participación de NNA en los conflictos armados, señala en sus dos primeros artículos lo siguiente:

\section{"Artículo 1}

Los Estados Partes adoptarán todas las medidas posibles para que ningún miembro de sus fuerzas armadas menor de 18 años participe directamente en hostilidades. 


\section{Artículo 2}

Los Estados Partes velarán por que no se reclute obligatoriamente en sus fuerzas armadas a ningún menor de 18 años".

Los estándares internacionales antes mencionados aportaron al Estado Colombiano para el diseño de la política pública nacional de primera infancia "Colombia por la primera infancia", expresada en el documento CONPES SOCIAL del 3 de diciembre de 2007.

Este puede considerarse como un verdadero antecedente en materia de política pública nacional frente a la problemática del reclutamiento ilícito de NNA, ya que permite realizar una aproximación a la atención de los NNA en contextos de violencia, a través de líneas estratégicas específicas, con el fin de orientar las acciones de la política pública de atención integral a la niñez tanto en el nivel nacional como en el territorial.

Estos lineamientos brindan orientación a los responsables de la política tanto en su formulación y ejecución, para que puedan dirigirla y priorizarla para el logro del desarrollo integral de la primera infancia, en tres enfoques a resaltar:

a. a. Garantizar la protección y restitución de los derechos de los NNA (en este ítem, plantea la necesidad de coordinar y fortalecer a las entidades responsables y los programas orientados a la protección de los NNA en situación de abandono, desnutrición, discapacidad, desplazamiento forzado, maltrato, abuso y peligro), dentro de los cuales también están los NNA en riesgo de reclutamiento.

a. b. Fomentar la participación de los niños y las niñas hasta los 6 años, de acuerdo con su nivel de desarrollo, y la inclusión por parte de los hacedores de políticas públicas en el desarrollo de programas y proyectos dirigidos a la primera infancia.

a. c. Promover el desarrollo integral de la primera infancia.

Uno de los puntos más importantes regulado por el CONPES SOCIAL de 2007, fue el de recomendar a los entes territoriales que expidan los lineamientos técnicos mínimos para la inclusión de la infancia y adolescencia en los planes de desarrollo, en el entendido que el Código de Infancia y Adolescencia "ordena la inversión y desarrollo de estrategias sectoriales e intersectoriales para priorizar la atención de la primera infancia en los territorios".

Otro antecedente importante es el Decreto 4690 de 2007. Este surge por iniciativa del Ministerio de Relaciones Exteriores en razón al acogimiento voluntario al monitoreo y presentación de informes de Resolución 1612 de 2005 del Consejo 
Seguridad de Naciones Unidas.

Con esta normatividad se crea la Comisión Intersectorial para la prevención del reclutamiento y utilización de niños, niñas y adolescentes por grupos organizados al margen de la ley, cuyo objeto es prevenir la vulneración de los derechos de niños, niñas y adolescentes, cuyo mandato incluye:

- $\quad$ Impulsar el cumplimiento y seguimiento de los compromisos y obligaciones internacionales en materia.

- $\quad \square \quad$ Reconocer a los niños, niñas y adolescentes como sujetos de derechos.

- $\quad \square \quad$ Diseñar políticas públicas idóneas, pertinentes y oportunas dirigidas a la garantía de sus derechos.

- $\square \quad$ Prevenir que sus derechos sean amenazados o vulnerados.

- $\quad$ Restablecer los derechos que han sido vulnerados.

Esta institución es considerada como una instancia intersectorial encargada de los roles destinados a orientar, coordinar, articular y hacer seguimiento a las acciones que adelanten las entidades estatales, tanto en el nivel nacional como en el territorial, en un marco de respeto por la descentralización administrativa, para prevenir la vulneración de los derechos de niños, niñas y adolescentes, principalmente frente al reclutamiento, utilización y violencia sexual por los grupos armados organizados al margen de la ley y por grupos delictivos organizados.

Como objetivos específicos tenemos los siguientes: a) promover el diseño y ejecución de políticas públicas de protección integral en los municipios focalizados y b) promover el fortalecimiento de entornos familiares, comunitarios e institucionales en los cuales los niños y las niñas estén y se sientan seguros, con el fin de disminuir los factores de riesgo que dan lugar a su reclutamiento, utilización y violencia sexual, por los grupos armados organizados al margen de la ley y por grupos delictivos organizados.

Así mismo, la Comisión intersectorial define nueve estrategias o principios fundantes, cada una con sus correspondientes líneas de acción, para el logro de sus objetivos específicos como son:

Estrategia 1: Articulación de la política intersectorial con las acciones que en prevención desarrollan la cooperación internacional, las instituciones públicas y privadas, nacionales, departamentales, distritales y municipales.

Estrategia 2: Promoción de una transformación en las familias y comunidades para generar entornos de protección y crear vigías de los niños y niñas.

Estrategia 3: Impulso a la prevención de las violencias físicas, sexuales y psicológicas contra la niñez y promoción del reporte de casos de riesgo y amenaza. 
Estrategia 4: Cartografía de Derechos para asegurar que la voz de los niños y niñas llegue a los Gobiernos Locales y se incluya en las políticas públicas.

Estrategia 5: Fortalecimiento y acompañamiento a los Gobiernos Locales focalizados para el diseño y ejecución de políticas públicas de protección integral a la niñez.

Estrategia 6: Trabajo de formación con adolescentes, funcionarios(as), comunidad, para prevenir la delincuencia juvenil y para prevenir su utilización por grupos de delincuencia organizada.

Estrategia 7: Movilización Social para sensibilizar y visibilizar el tema con el fin de decir "No" al reclutamiento de niños y niñas y a las diversas vulneraciones de sus derechos.

Estrategia 8: Ruta de Prevención Urgente, con el fin de consolidar protocolos de actuación en casos de amenaza o riesgo colectivo de reclutamiento contra niños y niñas.

Estrategia 9: Ruta de Prevención en Protección, con el fin de consolidar un protocolo de actuación en casos de amenaza o riesgo directo individual de reclutamiento contra niños y niñas (Consejería DDHH, Presidencia de la República, Secretaría Técnica de la Comisión Intersectorial de Prevención del Reclutamiento y Utilización de Niños, Niñas y Adolescentes, 2012).

En el año 2012, se expidió el Decreto 0552 de 2012, el cual amplio la conformación de sus miembros permanentes con voz y voto de 9 a 22 e incluyó la variable de violencia sexual en su denominación.

Luego en 2014, el Decreto 1649 que modifica la estructura del DAPRE, estableció en el numeral 16 del artículo 26, que la Consejería Presidencial para los DDHH ejercerá la Secretaría Técnica de la Comisión Intersectorial para la prevención del reclutamiento, utilización y violencia sexual contra niños, niñas y adolescentes, por grupos organizados al margen de la ley y por grupos delictivos organizados.

Con el propósito de facilitar la coordinación y articulación entre las 23 entidades que conforman la Comisión Intersectorial, el Decreto 1649 de 2014, dispone que la Secretaría Técnica de esta instancia sea ejercida por la Consejería Presidencial para los Derechos Humano.

Las principales funciones de la Comisión intersectorial son: coordinar, orientar, diseñar, ejecutar, realizar el seguimiento y evaluación de proyectos, planes, programas, estrategias y políticas públicas de prevención de reclutamiento, utilización y violencia sexual contra niños, niñas y adolescentes por grupos armados 
al margen de la ley y grupos delictivos organizados, en el ámbito territorial, atendiendo los principios y enfoque de protección integral, el principio de corresponsabilidad, prevalencia de derechos e interés superior del niño, junto con las propuestas de priorización municipal presentada por la Secretaría Técnica, para la definición de los departamentos, municipios y/o distritos en los que se desarrollarán las acciones de prevención, en donde debe propiciar los mecanismos de articulación Nación- Territorio para orientar la ejecución de los proyectos, planes, programas, estrategias y políticas públicas en esta materia.

\subsubsection{Documento 3673 de 2010}

Con el documento CONPES 3673 de 2010, el Estado colombiano formuló la política pública de prevención del reclutamiento y utilización de NNA por parte de grupos armados organizados al margen de la ley y de grupos organizados. En esta se incorporan los principales instrumentos internacionales reseñados previamente, se recoge la normatividad nacional en el tema y lo consignado en el Plan Nacional de Desarrollo 2006-2010 Estado Comunitario "Desarrollo para Todos". Igualmente, se recogen las recomendaciones realizadas por el Secretario General de las Naciones Unidas en el marco del Mecanismo de Seguimiento y Presentación de Informes de la Resolución 1612 de 2005 y del Comité de los Derechos del Niño.

Fue estipulado como objetivo principal prevenir el reclutamiento y utilización de NNA, por parte de los grupos armados organizados al margen de la Ley y de grupos delictivos organizados, garantizando la prevalencia, el goce efectivo de los derechos y la protección integral por parte de la familia, la sociedad y el Estado, y como objetivos los siguientes:

a. a. Generar y fortalecer las herramientas de protección integral de los niños, niñas y adolescentes en sus espacios vitales, prioritariamente en zonas con presencia (ocasional, frecuente o transitoria) de grupos armados que los reclutan y utilizan.

b. b. Contrarrestar las diversas formas de violencia y explotación ejercidas contra los niños, niñas y adolescentes en sus redes y entornos familiar y comunitario, garantizando la protección integral de sus derechos.

c. c. Garantizar una adecuada, asertiva, pertinente y eficaz oferta institucional, en lo nacional y territorial, para el pleno ejercicio y garantía de los derechos de los niños, niñas y adolescentes.

d. d. Promover el reconocimiento de los niños, niñas y adolescentes como sujetos de derechos, en sus entornos familiar y comunitario y redes sociales significativas. 
Además de lo anterior, el CONPES 3673 de 2010, buscó articular las siete estrategias y líneas de acción de la Política Intersectorial de Prevención con planes, programas y acciones que desarrollan algunas entidades estatales, organizaciones sociales y entidades territoriales. Algunas de dichas estrategias son:

A. A. "Articular la política intersectorial de prevención con las políticas, planes y programas de las entidades nacionales, internacionales, regionales, sociales o públicas en prevención de reclutamiento y utilización de niños y niñas.

B. B. Impulsar una transformación cultural en las familias, en las comunidades y en las instituciones para que niños, niñas, adolescentes y jóvenes sean reconocidos como sujetos de derechos.

C. C. Vitalizar y consolidar las redes familiares, sociales e institucionales para prevenir las formas de violencia contra la niñez y gestar vigías de los derechos de la niñez.

D. D. Fomentar la participación de niños, niñas y adolescentes mediante el desarrollo de la cartografía de derechos de niños y niñas.

E. E. Fortalecer los Consejos de Política Social y los Comités, Redes o Mesas de Infancia para el diseño y ejecución de políticas públicas de protección integral a la niñez y prevención del reclutamiento.

F. F. $\quad$ Promover la educación legal con adolescentes, jóvenes y comunidades de las casas de justicia y centros de convivencia para prevenir la delincuencia y el reclutamiento y utilización.

G. G. Movilizar a la sociedad para que la violación a los Derechos de los niños y niñas, incluido su reclutamiento y utilización por grupos organizados al margen de la ley, sea rechazada y reportada”. (Defensoría del Pueblo, 2014).

Conforme al bloque de constitucionalidad en materia de reclutamiento ilegal de NNA, y según el documento antes referido, son considerados principios orientadores en materia de prevención:

- $\quad$ Corresponsabilidad: es entendido como la concurrencia de actores y acciones conducentes a garantizar el ejercicio de los derechos de los NNA; según el Código de Infancia y Adolescencia la familia, la sociedad y el Estado son corresponsables de su atención, cuidado y protección. 
- Derecho a ser protegidos de su vinculación a grupos armados y a la participación.

- $\quad$ Enfoque de derechos: las actuaciones del Estado, la sociedad y la familia deberán observar la prevención, protección, promoción, garantía, restablecimiento, desarrollo y goce efectivo de los derechos de los NNA.

- Diversidad étnica: las actuaciones estatales deben respetar, promover y garantizar la diversidad étnica, reconocimiento sus particulares, características y cosmovisiones (art. 8 Carta Magna).

- $\quad$ Enfoque diferencial: Los derechos de los NNA tiene un carácter diferencial respecto a quienes son mayores de edad, por lo que se requiere de políticas diferenciales en las que se incluyan las situaciones de amenaza y vulneración de derechos.

- $\quad$ Perspectiva de género: de conformidad con lo estipulado en la ley 1098 de 2006, esta se define como el reconocimiento de las diferencias sociales, biológicas y psicológicos en las relaciones entre las personas según el sexo, la edad, la etnia y el rol que desempeña en la familia y el grupo social.

- Principios operativos. Conforme a los principios de Paris estos son: programación específica según el contexto, fortalecimiento de capacidades, financiamiento y otro tipo de apoyo a la prevención del reclutamiento ilegal o utilización, liberación y reinserción de NNA, coordinación, colaboración y cooperación, confidencialidad e información compartida y cobertura de medios de comunicación.

- Interés superior del niño: las autoridades públicas y privadas que deben tomar decisiones en relación con el NNA tienen la obligación de observar el bien mayor y ponderar las decisiones en relación estricta con la garantía y el ejercicio de los derechos, ciñéndose a la normatividad nacional e internacional.

- Prevalencia de derechos: este principio debe reflejarse en la formulación e implementación de políticas públicas.

- $\quad$ Protección integral.

- $\quad$ Ciclo de vida: La ley 1098 de 2006 estima las siguientes etapas del ciclo de vida de toda persona menor de 18 años: a. Primera infancia (0 a los 6 años), infancia (7 a los 12 años) y adolescencia (13 a 18 años). 
(Vicepresidencia de la República, DNP, OIM, Equipo Técnico Interinstitucional, |2011).

\subsubsection{Rutas de Prevención}

Respecto a la aplicación de las políticas de prevención del reclutamiento establecidos en el documento CONPES 3673 de 2010 y por el comité intersectorial para la prevención del reclutamiento y utilización de NNA por grupos organizados al margen de la ley y grupos de delincuencia organizada (2010, pág. 22), se reconocen tres rutas de prevención para los NNA en situación de vulnerabilidad: prevención temprana-mediana plazo, Prevención urgente (corto plazo) y Prevención en Protección (Acción Inmediata).

a. a. Prevención temprana - mediano plazo: Se encuentra conformada por las acciones que deben desarrollar las entidades estatales, la sociedad y la familia, con fundamento en el principio de corresponsabilidad regulado en el art. 10 del Código de Infancia y Adolescencia, en aras de adoptar todas las medidas necesarias para garantizar el ejercicio y la protección de los derechos de los niños, niñas y adolescentes, con el fin de prevenir su reclutamiento y utilización (principio de protección integral, art. 7 de la ley 1098 de 2006).

Esta ruta se activa en contextos donde existe presencia de los actores organizados al margen de la ley (grupos armados organizados, paramilitares, grupos de delincuencia común), economías ilícitas, corredores del narcotráfico, prácticas de micro tráfico, minas antipersonales, mina antipersonal, altos índices de violencia y explotación contra los NNA, con niveles significativos de pobreza y marginalidad, en donde el entorno de protección de los mismos son débiles o no existen, la presencia institucional es escasa y existen pocas oportunidades para la niñez y la adolescencia; Generalmente, se refiere a municipios reportados en los informes de riesgos de la Defensoría del Pueblo y con alertas tempranas emitidas (Comisión Intersectorial para la Prevención del Reclutamiento, la Utilización y la Violencia Sexual contra Niños, Niñas y Adolescentes por grupos armados al margen de la ley y por grupos delictivos organizados, 2014, pág.15)

Para desarrollar esta ruta el Conpes define dos estrategias:

- $\neg$ Implementación de las siguientes líneas de acción:

$\supset \supset$ Articulación de acciones

$\supset$ つ. Transformación de comportamientos en familia comunidad e instituciones, a través de la: 
- Prevención de todas las formas de violencia.

- Participación de niños, niñas y adolescentes.

- Acompañamiento a los Consejos Municipales de Políticas social en el diseño de políticas públicas de infancia y adolescencia.

- Prevención de la delincuencia juvenil.

- Movilización social para rechazar y reportar las violaciones a los derechos de los NNA.

- Ejecución de los planes de acción de las entidades nacionales, que se comprometieron con la Política de Prevención del Reclutamiento y Utilización.

a. b. Prevención urgente (corto plazo): Su aplicación se da en un momento previo cuando no existen señalamientos o familias o personas determinadas, sino que se cierne sobre una amenaza colectiva proferidas por grupos armados organizados al margen de la ley y por grupos delictivos organizados, tales como censos a escuelas, boleteos u ofertas de servicios ilegales. Sobre dichas amenazas deben iniciarse acciones urgentes lideradas por autoridades públicas o indígenas, según el caso, presentes en el municipio y en articulación con actores sociales. Para activar esta ruta, se implementan las siguientes líneas de acción:

a. a) Fortalecimiento de redes familiares, comunitarias e institucionales entorno a los niños, niñas y adolescentes en riesgo.

a. b) Gestión urgente de las autoridades públicas locales para rodear a los niños y niñas en contra de las amenazas, mediante el fortalecimiento de programas, proyectos e iniciativas deportivas, lúdicas, culturales, sociales y pedagógicas.

a. c. Prevención en Protección (Acción Inmediata): Actúa sobre amenazas individuales directas, proferidas contra niños, niñas, adolescentes o grupos de éstos. Para activar esta ruta se realizan las siguientes acciones:

Conformación y activación de un grupo de acción inmediata en el municipio, conformado por autoridades públicas, líderes comunitarios, organizaciones sociales, cooperación internacional, entre otros actores.

Movilización para la protección del NNA amenazado:

Sin su familia o cuidadores: la autoridad pública apoyada por líderes comunitarios y/o indígenas gestiona recursos para el traslado a un lugar físico seguro y notifica a la autoridad competente (Defensor de Familia, Comisario de Familia o Inspector de Policía) para el seguimiento de caso.

Con su familia o cuidadores: las autoridades públicas apoyan el traslado de la familia a un lugar seguro. La personería (municipal o distrital) comunica 
a Acción Social sobre el caso de desplazamiento a causa de una amenaza de reclutamiento forzado. Esta Entidad, a su vez, inscribe a la familia en el registro único, entrega ayuda humanitaria de emergencia y notifica el caso ante la autoridad competente, que decidirá otras medidas a que haya lugar. (Vicepresidencia de la República, DNP, OIM, Equipo Técnico Interinstitucional, |2011).

\subsection{Lineamientos de la política pública para la prevención del reclutamiento en los departamentos y municipios en Colombia.}

La Vicepresidencia de la República, el Ministerio de Educación Nacional, Ministerio de Salud y Protección Social, Departamento Administrativo para la Prosperidad Social, ICBF, con apoyo de las Naciones Unidas y el Fondo de las Naciones Unidas para la Infancia UNICEF, desarrollaron en el 2007 un documento denominado Marco de Políticas Públicas y Lineamientos para la Planeación del Desarrollo de la Infancia y Adolescencia en el Municipio con un Enfoque de Derechos y de Conformidad con la ley, de ciclo de vida, de garantía y de restablecimiento de derechos en el Departamento y en el Municipio.

Según este, bajo la aplicación del principio de corresponsabilidad tanto a nivel político, social e institucional del Estado, la sociedad y la familia, y el principio del interés superior, la protección integral de los derechos de los NNA contempla cuatro tipos de acciones conforme a la regulación de la Convención Internacional de los Derechos del Niño: el reconocimiento, la garantía, la prevención y el restablecimiento, por cuanto los derechos fundamentales de los NNA posee cinco características esenciales tendientes orientar la gestión pública tanto en el ámbito nacional como local: la universalidad, exigibilidad, invisibilidad, progresividad.

Los derechos fundamentales de los NNA, se orientan a cuatro aspectos fundamentales:

A. A. Existencia: Hacen referencia a las condiciones esenciales para preservar la vida de los NNA, los cuales se concretan en los siguientes tópicos: a. Ser deseado. b. Ser querido y respetado. c. Que la madre y su hijo tengan atención durante el embarazo y el parto. d. No morir por causas que pueden evitarse. e. No enfermarse cuando puede prevenirse y ser atendido cuando se enferma. g. Conocer a sus padres, estar con su familia y ser cuidado por ella. h. Estar bien nutrido. i. Tener acceso a agua potable. j. Vivir en un ambiente sano.

A. A. Desarrollo: Aluden a los derechos fundamentales que permitan las 
condiciones básicas para el progreso y desarrollo digno de los NNA, a través del ejercicio de facultades como: A. Poder jugar, porque el juego es esencial para el desarrollo físico y mental. B. Tener educación. C. Poder descansar. D. Contar con las condiciones adecuadas para su desarrollo afectivo, físico, mental y social.

B. B. Ciudadanía: que sean tratados como ciudadanos (es decir, como personas participantes, como titulares de derechos y obligaciones) y que tengan las condiciones básicas para la vida en sociedad y ejercer la libertad, como: A. Estar registrado. B. No ser discriminado por ser diferente o pensar diferente. C. Reconocer que tenemos diferencias por sexo, etnia, cultura y edad. D. Tener acceso a la información y la cultura. E. Poder expresarse, opinar libremente y ser escuchados. F. Poder asociarse y reunirse. G. Participar y ser tenido en cuenta. H. Tener intimidad. I. Si viola la ley, tener el proceso debido y si fuera del caso, una sanción correspondiente con su edad y una adecuada rehabilitación.

A. A. Protección: que no sean afectados por factores perjudiciales para la integridad humana, como: A. No ser abandonado. B. No estar en situaciones de riesgo. C. No ser maltratado jamás ni por nadie. D. No ser descuidado y no ser objeto de abuso físico, sexual o mental. E. No ser involucrado en conflictos armados o situaciones similares. F. No ser secuestrado o utilizado como objeto de tráfico. G. No ser explotado y no tener trabajos perjudiciales para su salud y su educación. H. No carecer de vivienda (Ministerio de la Protección Social (2009), pág. 19).

Dentro de las garantías para la Infancia y la Adolescencia según la etapa de desarrollo, dentro del tópico de protección se busca que ningún niño sea víctima de violencia organizada, estableciéndose como objetivos: a. Prevenir el reclutamiento y utilización por grupos armados al margen de la ley y grupos delictivos organizados. b. Proteger y garantizar la restitución de todos sus derechos a las víctimas de la acción de grupos armados y el desplazamiento forzado.

Estos lineamientos se encuentran dentro del marco constitucional desarrollado por la Corte Constitucional en su jurisprudencia, la cual considera que los derechos fundamentales de los niños, niñas y adolescentes gozan de una especial protección tanto en el ámbito internacional como en nuestro Estado Social de Derecho, en razón a su situación de indefensión, vulnerabilidad y debilidad de esta población y la necesidad de garantizar un desarrollo armónico e integral de la misma, derroteros que fueron recogidos en el Código de Infancia y Adolescencia, en su estructura normativa. 
Los niños, en virtud de su falta de madurez física y mental -que les hace especialmente vulnerables e indefensos frente a todo tipo de riesgos-, necesitan protección y cuidados especiales, tanto en términos materiales, psicológicos y afectivos, como en términos jurídicos, para garantizar su desarrollo armónico e integral y proveer las condiciones que necesitan para convertirse en miembros autónomos de la sociedad (Corte Constitucional, 2012, Sentencia T-260, M.P. Sierra Porto H.).

A nivel territorial, esta política pública estableció como funciones centrales de los alcaldes y los gobernadores en materia de derechos humanos frente a su comunidad:

-Ser representante del Estado ante la comunidad local.

-Ser representante y vocero de la comunidad local ante el Estado.

Complementariamente al anterior marco de política pública, fue elaborado el Plan Nacional para la Niñez y la Adolescencia 2009-2019, en el cual se identifica las acciones y responsabilidades del Estado en esta temática, al igual que establece doce objetivos de relevancia, tomando el referente de la clasificación de los derechos fundamentales de los NNA mencionados en el Marco de Políticas Públicas y Lineamientos para la Planeación del Desarrollo de la Infancia y Adolescencia en el Municipio con un Enfoque de Derechos y de Conformidad con la ley, de ciclo de vida, de garantía y de restablecimiento de derechos en el Departamento y en el Municipio.

\section{Existencia:}

- Todos vivos (que ninguno muera cuando puede evitarse).

- Ninguno sin familia.

- Todos saludables.

- Ninguno desnutrido o con hambre.

\section{Desarrollo}

- Todos con educación de calidad y no discriminante.

- Todos jugando.

- Todos capaces de manejar los afectos y las emociones.

\section{Ciudadanía}

- Todos registrados.

- Todos participando en la vida de la comunidad. 


\section{Protección}

- Ninguno maltratado o abusado.

- Ninguno en una actividad perjudicial o violenta.

- Los adolescentes acusados de violar la ley con debido proceso y sanciones educativas y Proporcionales.

Dentro del Poder Ejecutivo, la estructura institucional responsable por la ejecución del Plan incluye al ámbito territorial (municipios, distritos y departamentos) y al ámbito nacional.

En el nivel municipal y distrital, la responsabilidad de orientar la ejecución de este Plan compete al Alcalde. Sus funciones principales son dos:

a. a) Coordinar en su municipio el conjunto de organismos que prestan servicios para la infancia y la adolescencia, incluyendo los que son de responsabilidad directa de la administración municipal y también los que son del orden departamental y nacional.

a. b) Ser representante y vocero de la niñez y la adolescencia ante todas las instancias que deben garantizar sus derechos, exigiendo y coordinando acciones de acuerdo con las condiciones específicas de su comunidad.

b.

Otra función de carácter complementario es la relativa a la prestación de servicios tendientes a la prevención de enfermedades y de las muertes evitables, la prevención del embarazo adolescente, la organización de servicios de alimentación, la provisión de áreas recreativas, la organización de mecanismos de asesoría para adolescentes, la provisión de agua segura, la orientación de la educación, el establecimiento de servicios de apoyo para adolescentes vinculados al sistema penal o el emprendimiento de acciones contra el maltrato y el abuso.

Para estos efectos, el Alcalde cuenta con el apoyo del Consejo Municipal de Política Social como instancia de coordinación, y con el Plan de Desarrollo Municipal como instrumento orientador de las acciones prioritarias.

En el nivel departamental, la responsabilidad de orientar la ejecución de este Plan corresponde al Gobernador. Sus funciones son tres: i) coordinar el conjunto de organismos que prestan servicios para la infancia y la adolescencia en su territorio; ii) orientar la prestación de los servicios a favor de las niñas, niños y adolescentes que son de su competencia -en sectores como salud, educación y ambiente-; y iii) apoyar la gestión de los municipios en favor de la infancia y la adolescencia. El Gobernador cuenta con el apoyo del Consejo Departamental de Política Social, cuya función es coordinar y promover las acciones de distintas entidades y sectores. El Plan de Desarrollo Departamental es el instrumento esencial para incluir los objetivos a lograr 
y definir las acciones y responsabilidades requeridas para su buen término.

En el nivel nacional, la responsabilidad básica por los resultados de este Plan compete al Presidente de la República y, por delegación suya y mandato legal, a todos los ministros. Sus funciones son:

i) dirección de la gestión pública a favor de los derechos de las niñas, niños y adolescentes, para constituirla en una política pública sólida, eficaz y sostenible; ii) garantizar la promoción de los derechos de las niñas, niños y adolescentes en todas las instancias de la gestión pública y la educación de la familia y la comunidad en este campo para un óptimo cumplimiento de sus corresponsabilidad; iii) ejercer la rectoría de los servicios que materializan los derechos de las niñas, niños y adolescentes, independientemente del carácter público o privado de los prestadores; iv) orientar la vigilancia administrativa del ejercicio de los derechos; y v) establecer los criterios y mecanismos de operación de las garantías restituidas a favor de las niñas, niños y adolescentes que sufren la violación o negación de un derecho.

Para cumplir estas funciones en materia de coordinación intersectorial, el presidente de la República cuenta con el apoyo del Consejo Nacional de Política Social, cuya secretaría técnica es ejercida por el ICBF. El Departamento Nacional de Planeación tiene la responsabilidad de recoger las directrices y planes definidos por el Consejo Nacional de Política Social y presentarlos al CONPES para que involucren e integren las responsabilidades de sectores no pertenecientes al Consejo Nacional y para afirmarlos en el ámbito de las grandes políticas nacionales (Ministerio de la Protección Social, 2009, Plan Nacional para la Niñez y la Adolescencia).

Conforme lo expuesto, desde el año 2007 se evidencia que a nivel nacional, el gobierno juntos con entidades de carácter internacional como la ONU y UNICEF, y otras de carácter nacional como la DEFENSORIA DEL PUEBLO, ICBF, MINISTERIO DE EDUCACIÓN entre otros, han venido preocupándose por cumplir con las obligaciones internacionales referentes a la temática de prevención y atención a víctimas del reclutamiento ilegal de NNA, pretendiendo implementar una política pública en ese sentido dentro de los mismos planes de desarrollo nacional, regional y local.

Por el contrario, en los municipios y departamentos, no han sufrido en el mismo nivel esta evolución, ante la falta misma del compromiso político, social, económico de sus gobernantes y de la misma comunidad.

\subsection{PLANES DE GOBIERNO DE LOS MUNICIPIOS DE CALAMAR, EL RETORNO Y MIRAFLORES DEL DEPARTAMENTO DE GUAVIARE EN}




\section{MATERIA DE RECLUTAMIENTO ILEGAL DE NNA.}

\subsubsection{Situación actual en materia de reclutamiento de NNA en el Departamento de Guaviare.}

El Departamento del Guaviare se encuentra localizado al Suroriente de Colombia en la región denominada de la Amazonía, el cual posee un área total de 55.791 kilómetros cuadrados, que equivalen a 5.579 .100 hectáreas, en el que se encuentra la reserva forestal del mismo nombre. Políticamente está conformado por cuatro municipios: San José, El Retorno, Calamar y Miraflores (Gobernación de Guaviare, 2012).

De acuerdo al Censo Nacional de Población y de Vivienda realizado por el DANE en el año 2012, el departamento alcanzó una población de 106.386 habitantes distribuidos así: 60.586 correspondían a las cabeceras municipales y 45.800 a la zona rural.

A pesar de la inmensa riqueza natural y cultural que existe en este departamento, este ha sufrido uno de los peores flagelos del mundo durante el último siglo como lo es el conflicto armado, el cual se ha nutrido en la actualidad por el narcotráfico y la presencia de grupos al margen de la ley en este territorio (guerrilla, paramilitares y BACRIM), con ocasión a la débil presencia del Estado, su situación geográfica en el país, la existencia de amplias extensiones forestales y rurales, el subdesarrollo urbano, frente a la consolidación del fortalecimiento económico y militar de los alzados en armas.

Ello ha traído como consecuencia el desplazamiento forzado, terrorismo, crisis humanitarias, disputas territoriales entre colonos e indígenas, enriquecimiento ilícito, aumento de la violencia y reclutamiento ilícito de NNA, campos minados, implementación de una economía ilegal basada en la producción y comercialización de drogas, secuestros, extorsiones; como efecto el Estado ha tenido que hacer presencia a través de las fuerzas armadas.

Teniendo en cuenta la dimensión de esta problemática, diversos organismos han realizado estudios e investigaciones para lograr concretar información sobre la situación actual del reclutamiento ilícito de NNA (Defensoría del Pueblo (2012). 
La Unidad para la Atención y Reparación Integral a las Victimas en el informe departamental de Guaviare respecto a los hechos victimizantes del año 2012, presenta el estudio de la cantidad de personas afectadas dentro del marco del conflicto armado sin hacer referencia a las posibles políticas gubernamentales o acciones de los distintos grupos armados, exponiendo como estadística lo siguiente:

\section{Tabla No. 2}

Fuente: Universo de Víctimas. Elaboración Red Nacional de Información-Grupo Análisis e Investigación

El total de víctimas que declararon que el hecho ocurrió en Guaviare es de 6,532 y la mayoría de ellas se encuentran en la categoría "homicidio" que agrupa al $60 \%$ de las mismas, seguida por "desaparición forzada" que agrupa al $22 \%$.

Por otra parte, en el departamento residen 2,125 víctimas, para las cuales el hecho más importante es homicidio con el $64 \%$ de las víctimas, seguido por desaparición forzada que abarca al $22 \%$.

Adicionalmente, en el departamento se encuentra que según ocurrencia hay 180 personas que no tienen definido el tipo de hecho, de las cuales algunas se incluyen en accidentes con munición sin explotar o minas antipersonales, información detallada más adelante en el apartado "minas antipersonal y accidentes con munición sin explotar”, (Unidad para la Atención y Reparación Integral de Victimas 2012).

Al realizar el análisis de la información se encuentran 6.352 personas afectadas por los diferentes hechos victimizantes de las cuales podemos identificar que se distribuyen en los cuatro municipios del departamento, el $61 \%$ de las víctimas se encuentran en San José del Guaviare, el 14\% en Miraflores, el 13\% en el Retorno y el 12\% en Calamar (Defensoría del Pueblo, 2012).

La Procuraduría General de la Nación durante el II Encuentro de Alcaldes y Alcaldesas por la Infancia, la Adolescencia y la Juventud que se llevó a cabo en la ciudad de Palmira (Valle del Cauca) el 31 de marzo de 2014, presentó un informe de vigilancia preventiva a la protección de los derechos de los niños, niñas y adolescentes víctimas del conflicto armado en 139 municipios de Colombia, en el cual expuso que de las 6'231.617 víctimas del conflicto armado registradas entre 1985 y 2013 , el 49,6\% corresponde a personas que tenían entre 0 y 26 años de edad 
en el momento de su victimización.

Las fuentes utilizadas fueron información emitida por la Unidad para la Atención y Reparación Integral a las Víctimas y el Departamento Administrativo Nacional de Estadística (DANE). Este informe fue elaborado con el propósito de evidenciar la situación de derechos de los menores de edad en los municipios prioridades por la Comisión Intersectorial para la Prevención del Reclutamiento Forzado (Procuraduría General de la Nación, (2014).

La Comisión Intersectorial para la prevención del reclutamiento, la utilización y la violencia sexual contra niños, niñas y adolescentes por parte de grupos armados al margen de la ley y grupos delictivos organizados, al cumplir la función de coordinar y orientar el diseño, ejecución, seguimiento y evaluación de proyectos, planes, programas, estrategias y políticas públicas de prevención en el ámbito territorial, elabora anualmente una propuesta de priorización municipal que facilita la definición de los departamentos, municipios y distritos en que debe orientarse de manera prioritaria el desarrollo de acciones de prevención en cuanto esta temática, propuesta que se realiza todos los años por la Consejería Presidencial de los Derechos Humanos y la Secretaría Técnica de la Comisión Intersectorial.

La priorización correspondiente para el año 2015, fue construida bajo la perspectiva del documento CONPES 3673 de 2010 y la ley 1098 de 2006, en conjunción con un enfoque de protección integral que implica una comprensión amplia del reclutamiento y la utilización y la violencia sexual contra niños, niñas y adolescentes en aras de brindar información destinada al diseño de políticas públicas y la definición de intervenciones del poder ejecutivo y entidades territoriales en cada fase de la ruta de prevención establecido por el mismo CONPES 3673 de 2010.

Para la elaboración de este documento fueron tomadas varias fuentes oficiales para alimentar la variable que corresponde a la presencia de reportes o casos de reclutamiento de NNA en cada uno de los 1.122 municipios del país. De esta manera se brindó el valor 1 a cada municipio que presentó la presencia de al menos 1 reporte, caso de reclutamiento, y el valor 0 a cada municipio que no presento ningún reporte. En él se planteó una clasificación de todos los municipios del país en cuatro grupos; los cuales fueron contrastados con la presencia institucional que las entidades reportaron en el marco del seguimiento a la implementación de las políticas de prevención (la información de presencia institucional responde a reportes periódicos 
institucionales solicitados por el Observatorio del respectivo comité y cuya última fecha de actualización corresponde al 21 de septiembre de 2015).

Tabla No. 3

\begin{tabular}{|l|l|l|}
\hline GRUPO & NIVEL PRIORIZACIÓN & No. MUNICIPIOS \\
\hline GRUPO A & NIVEL MEDIO & 456 \\
\hline GRUPO B & NIVEL SUPERIOR BAJO & 198 \\
\hline GRUPO C & NIVEL SUPERIOR MEDIO & 291 \\
\hline GRUPO D & NIVEL SUPERIOR ALTO & 177 \\
\hline
\end{tabular}

En este sentido, para el departamento del Guaviare se encuentra en el grupo D nivel superior alto con mayor índice de probabilidad de ocurrencia de casos de reclutamiento / utilización. Representa el 16\% del total nacional y está indicado por niveles de probabilidad entre 0.9 y 1.0 , sin importar si tienen altos niveles en reportes en promedio para su región.

En el Nivel Superior Alto sombreado de color rojo, se encuentran todos aquellos municipios con probabilidades mayor o igual a 0.9. Para establecer este grupo no se tuvieron en cuenta el número de reportes, ya que el valor de la probabilidad se consideró criterio suficiente como para evitar sacar un municipio que tuviera reportes inferiores al promedio de su unidad territorial. Este grupo está conformado por 177 municipios (Secretaria Técnica de la Comisión Intersectorial para la prevención del reclutamiento, la utilización y la violencia sexual contra niños, niñas y adolescentes por parte de grupos armados al margen de la ley y grupos delictivos organizados, 2015, pág. 14)

De lo expuesto se infiere que el departamento de Guaviare se encuentra a nivel estadístico en un nivel superior alto de nivel de priorización de reclutamiento de NNA al presentarse un número de casos superiores al índice de intervención que se presenta en otros departamentos.

\subsubsection{Factores y riesgos que inciden en el reclutamiento ilícito de NNA en los municipios de Calamar, Miraflores y Retorno del Departamento de Guaviare.}

Según Directiva Transitoria 2013- 15 de fecha 28 de agosto de 2013 del Ministerio de Defensa Nacional, se establece las instrucciones para implementar la estrategia que deben utilizar este ente centralizado para la prevención del 
reclutamiento y utilización de niños, niñas y adolescentes, por parte de los grupos armados organizados al margen de la ley y grupos de delincuencia organizada a las fuerzas militares y policía nacional.

Por motivo que este documento no establecía los parámetros claros de ejecución a nivel Brigada y Batallón para lo pertinente, y ante su desconocimiento por los miembros de la institución, se determinó la creación de la Directiva No 206 / MDN-CGFM-CE-DIV4-GAC-PREV, en el cual exponen varios aspectos de esta problemática.

Teniendo en cuenta que la fuerza pública ha tenido una presencia directa en la región, se ha observado que los entornos familiares y comunitarios están empezando a aceptar a nivel cultural la oferta institucional concerniente al respeto y garantía de los derechos de los niños, niñas y adolescentes, por motivo que ya no ven a la FARC como una opción de vida o solución laboral que en algún momento pensaron que mejorarían sus condiciones y necesidades básicas, al perder su estado ideológico, político y de masas.

A pesar de ello, las fuerzas al margen de la ley, han buscado utilizar mecanismos para su fortalecimiento. Las juntas de acción comunal y la junta de acción local, fueron para el período comprendido entre el 2010 y 2015 un importante blanco que las FARC, tiene para el logro de su objetivo estratégico de control territorial y dominio de la población civil, convirtiéndose sus líderes comunitarios en verdaderos interlocutores de su ideología y proyecciones delictivas, a la vez que son herramienta fundamental para obtener un espacio claro y abierto de intervención para lograr reclutar personal a sus filas delictivas.

Para las fuerzas armadas, los factores de riesgo como mecanismos empleados por la FARC para el control sobre el territorio son las siguientes: precarias condiciones económicas y socioculturales de la población civil, trabajo proselitista en centros educativos ubicados en áreas críticas aprovechando la desatención y descuido por parte de entes gubernamentales, ofrecimiento de mejorar nivel de vida a los jóvenes por parte de los grupos organizados armados al margen de la ley, seducción mediante la utilización de las armas y poder, adoctrinamiento ideológico, ausencia del estado, intimidación, escasos e incipientes programas de Gobierno en áreas difíciles y escasos recursos, falta de oportunidades, economía basada en la ilegalidad (cultivos ilícitos, laboratorios, microtráfico, etc.), la cuota familiar, la desigualdad social extrema, la pobreza y la falta de oportunidades para lograr una mejor situación y bienestar, violencia sexual, matoneo escolar, deseo de venganza, entre otros 
(Gobernación de Guaviare, 2012, Proyecto de Ordenanza Plan de Desarrollo Departamental, 2012- 2015) .

Los actores del reclutamiento forzado han sido frecuentamente: milicianos, amigos que están vinculados con estos grupos, docentes, comandantes de frentes o de escuadra, etc.

Los motivos por los cuales vinculan a los NNA son: vinculación directa en combate, reclutados para la estructura operativa, para raspar, como informantes y luego como combatientes, las niñas son utilizadas como esclavas sexuales de los comandantes, también son empleadas para actividades de inteligencia, logísticas, señuelos para incrementar niveles de reclutamiento y objeto sexual (prostitución).

Los medios de acercamiento que se utilizaban para reclutar a los NNA son a través de milicias en la zona urbana y rural, es a través de las escuelas con presencia directa, en los caminos de la casa a la Escuela; las BACRIM aprovechan espacios de esparcimiento, deportivos y culturales en la zona rural, internados, presencia directa en reuniones comunitarias, realización de actividades lúdicas y culturales, y clubes Infantiles Bolivarianos.

Por otro lado, la Secretaria Técnica Intersectorial para la prevención del reclutamiento, la utilización y la violencia sexual contra niños, niñas y adolescentes por parte de grupos armados al margen de la ley y grupos delictivos organizados, en el documento denominado "Construcción de un Plan de Protección Integral de Niños, Niñas y Adolescentes", por iniciativa de la Secretaría del Gobierno del Departamento de Guaviare, realizó una actualización de datos obtenidos en el año 2014, para la identificación y georreferenciación de factores de riesgo presentes en los Municipios de Calamar, Retorno y Miraflores, los cuales se resumen en los siguientes:

\section{a. a. Municipio de Calamar}

Los factores de riesgo que inciden principalmente en el reclutamiento ilícito de NNA en el Municipio de Calamar en el Departamento de Guaviare, son: -Presencia o tránsito de grupos organizados al margen de la ley y grupos delictivos. -Presencia de economías y actividades ilegales y zonas de transito de las actividades ilegales.

-Altos índices de homicidio.

-Presencia de minas antipersonales. 
-Altos índices de violencia sexual e intrafamiliar contra niños, niñas y adolescentes.

-Trabajo infantil.

-Regiones deprimidas por bajos índices económicos y de marginalidad social.

-Población con pertenencia étnica superior a $13.6 \%$.

-Amenazas a población LGTB por parte de delincuencia común.

-Consumo de sustancias psicoactivas.

-Mal estado de las vías.

\section{b. Municipio de Miraflores}

Los factores de riesgo que inciden principalmente en el reclutamiento ilícito de NNA en el Municipio de Miraflores en el Departamento de Guaviare son:

-Presencia o tránsito de grupos organizados al margen de la ley y grupos delictivos organizados.

-Presencia de economías y actividades ilegales y zonas de transito de las actividades ilegales.

-Altos índices de homicidio.

-Presencia de minas antipersonales.

-Altos índices de violencia sexual e intrafamiliar contra niños, niñas y adolescentes.

-Trabajo infantil.

-Regiones deprimidas por bajos índices económicos y de marginalidad social.

-Población con pertenencia étnica superior a $13.6 \%$.

-Minería ilegal.

-Zonas donde no hay presencia de fuerza pública de manera permanente.

-No presencia institucional.

\section{c. Municipio del Retorno}

Los factores de riesgo que inciden principalmente en el reclutamiento ilegal de menores en el Municipio de Miraflores en el Departamento de Retorno son:

-Presencia o tránsito de grupos organizados al margen de la ley y grupos delictivos organizados.

-Presencia de economías y actividades ilegales y zonas de transito de las actividades ilegales.

-Altos índices de homicidio.

-Presencia de minas antipersonales.

-Altos índices de violencia sexual e intrafamiliar contra niños, niñas y adolescentes. 
-Trabajo infantil.

-Regiones deprimidas por bajos índices económicos y marginalidad social.

-Población con pertenencia étnica superior a $13.6 \%$.

-Falta de acceso a salud, educación superior, TICS y vías de acceso.

-Falta de proyectos productivos y generación de ingreso, presencia institucional y oferta. (Secretaria Técnica Intersectorial para la prevención del reclutamiento, la utilización y la violencia sexual contra niños, niñas y adolescentes por parte de grupos armados al margen de la ley y grupos delictivos organizados, (2015).

La Defensoría del Pueblo ha señalado que la mayor parte del territorio de los Municipios del Retorno y Calamar es plano y ondulado, compuesto por dos unidades fisiográficas definidas: la primera, ocupa la mayor extensión y corresponde a una gran planicie donde predominan las áreas onduladas; la segunda, conocida como "vega de río", en la que sobresalen la serranía y la mesa de la lindosa, los cerros Paloma y Santa Ana y la sierra de Chibiriquete. Esta situación geográfica ha permitido que se convierta en una zona de retaguardia de las Farc al permitir el ocultamiento, entrenamiento, avituallamiento, y recomposición de tropas $y$ delineamiento de la economía de guerra basada en los cultivos de coca; sin embargo, el boleteo y la extorsión a ganaderos, comerciantes y transportadores, hacen parte de sus fuentes de financiación y la obtención de recursos. La selva tiene un papel fundamental en el conflicto armado, por cuanto se constituye en una barrera natural que proporciona una ventaja estratégica para protegerse, disimularse, descansar y abastecerse (Defensoría del Pueblo, 2014).

La guerrilla de las FARC, utiliza los territorios indígenas y las fincas de los no indígenas, para transitar y evadir encuentros con la fuerza pública; a su paso, someten a las comunidades, ubicadas en las zonas más apartadas y carentes de apoyo y asistencia estatal, a estrategias de control social relacionadas con imposiciones y severas restricciones para el libre tránsito dentro del territorio o para sus traslados hacia las cabeceras municipales (Gobernación de Guaviare, 2012).

El Municipio de Miraflores se localiza en zonas selváticas del departamento Guaviare, en un territorio cuyas condiciones geográficas favorecen el entrenamiento, ocultamiento y avituallamiento de los grupos armados ilegales, además, brinda ventajas estratégicas para actividades delictivas como el tráfico de armas, insumos y derivados de la producción cocaínera a través de la cuenca del río Vaupés, en dirección a las fronteras con Brasil y Venezuela, pasando por los departamentos Vaupés y Guainía (Gobernación del Guaviare, 2012).

La población está conformada por el indígena nómada y seminómada, y por colonos quienes aprovechan la producción y comercialización de coca, como medio 
de ingresos en sus economías familiares, lo que permitió la expansión del actuar de los grupos ilegales (Defensoría del Pueblo, 2012).

\subsubsection{Planes de gobierno existentes durante el periodo de 2010 a 2015 para la prevención del reclutamiento ilícito de NNA en los Municipios de Calamar, Retorno y Miraflores.}

La Procuraduría General de la Nación durante el II Encuentro de Alcaldes y Alcaldesas por la Infancia, la Adolescencia y la Juventud que se llevó a cabo en la ciudad de Palmira (Valle del Cauca) el 31 de marzo de 2014, presenta un informe en el cual, como Ministerio Público evidenció debilidades relacionadas con la precisión de la situación de derechos de los niños, niñas y adolescentes en el diagnóstico de la situación actual en materia de reclutamiento ilegal por fuerzas al margen de la ley.

El informe concluye que los niños, niñas, adolescentes y jóvenes víctimas del conflicto armado deben ser prioridad en la garantía y en el restablecimiento de derechos hoy, en un posible acuerdo, en el postacuerdo, y en el postconflicto, para lo cual se requiere el fortalecimiento de la gestión pública territorial, con una efectiva y eficaz articulación Nación - territorio, y que no es suficiente una priorización de municipios si no va acompañada de una priorización de inversión social. (Procuraduría General de la Nación, 2014).

De igual manera la Secretaria Técnica Intersectorial para la prevención del reclutamiento ilícito, ha detectado como falencias en la implementación de la política pública en esta materia a nivel territorial los siguientes tópicos: la diversidad de enfoques existentes (siendo el de menor presencia el enfoque de derechos y diferencial); la oferta de servicios generalizada (no es precisa en relación al factor de riesgo específico); la ausencia de estrategias o mecanismos de monitoreo, seguimiento y evaluación, falta de fortalecimiento de capacidades en los territorios, falta de articulación entre los entes que conforman la estructura de la política pública en materia de reclutamiento ilícito, e incompleta cobertura en relación con la priorización municipal conforme a la ruta establecida por el gobierno nacional a través de la Comisión Intersectorial conforme la información publicada a través de cartillas informativas al respecto, y asesorías que presta este ente, del cual se evidencia que no se están utilizando eficazmente estos mecanismos por algunos entes territoriales (Secretaria Técnica Intersectorial para la prevención del reclutamiento, la utilización y la violencia sexual contra niños, niñas y adolescentes por parte de grupos armados al margen de la ley y grupos delictivos organizados,2015). 
De igual manera la Defensoría del Pueblo emite unas recomendaciones dirigidas a las entidades territoriales, resaltándose que para el caso de la Gobernación del Guaviare, este ente ha tenido una evolución lenta en la implementación de esta política pública, por ello se aconseja:

-A las gobernaciones de Meta, Guaviare, Guainía y Vichada, la instalación y puesta en marcha del Comité Departamental de prevención del reclutamiento y utilización ilícita de NNAJ. Dicho comité se debe encargarse de la articulación y coordinación interinstitucional e intersectorial para la prevención y la protección en el nivel departamental y del apoyo técnico a los municipios para el desarrollo de las rutas de prevención (temprana, urgente y en protección) y de atención frente al reclutamiento ilícito y la utilización de niños, niñas y adolescentes.

-A las secretarias departamentales de salud, educación, integración social, desarrollo, gobierno de las gobernaciones de Meta, Guaviare, Guainía y Vichada, en el marco legal de

sus funciones, articular acciones para llevar a cabo las directrices enmarcadas en el Comité Departamental de prevención del reclutamiento y utilización de NNAJ por grupos armados ilegales.

-Las Gobernaciones de Meta, Guaviare, Guainía y Vichada y las alcaldías de los municipios identificados en riesgo, establecer planes de acción, en el marco de su política social para la niñez y la adolescencia, para la ejecución de las rutas de prevención urgente y de prevención en protección, así como para el fortalecimiento de los entornos protectores identificados en el marco del Conpes 3673 de 2010. (Defensoría del Pueblo, 2012).

Por último, la Comisión Intersectorial de prevención del reclutamiento y la utilización de niños y niñas y adolescentes por grupos organizados al margen de la ley identificó que las entidades miembros están actuando de manera independiente, sin una coordinación y articulación entre sí. Por tal motivo, emite una cartilla informativa en la que expone un esquema de confluencia de planeaciones y mandatos de articulación, específicamente en el tema de Prevención de Reclutamiento y Utilización.

De allí que la Comisión Intersectorial al cumplir la función de articulación institucional de sus miembros, plantea un esquema de confluencia de marcos de planeación, con los Planes de Desarrollo locales como base, en los que se puedan 
implementar a nivel local la política pública desarrollada a nivel a través de dos planes conocidos como Planes locales de desarrollo en municipios prioritarios y planes integrales de prevención.

Para el caso del Municipio de Calamar, propone que se adopte dentro del plan de desarrollo municipal los siguientes planes o programas:

-Dotación a las instituciones educativas con material didáctico y pedagógico, elementos de laboratorio y demás necesarios para su normal desarrollo.

-Entrega de kits escolares a NNA víctimas del conflicto armado.

-Desarrollo e implementación de un programa de nutrición para niños bajo de peso o con desnutrición en el municipio, con énfasis en población víctima y extrema pobreza.

-Fortalecimiento del comité interinstitucional consultivo para la prevención de la violencia sexual y atención integral de las NNA víctimas de abuso sexual.

-Organización, dotación y ejecución de eventos deportivos y recreativos comunitarios interveredales para la promoción de estilos de vida.

-Dotación, promoción y apoyo a los programas de formación y divulgación de las expresiones culturales de infantes y adolescentes (Escuela de Formación Tejiendo Cultura).

-Garantizar que las niñas, niños y adolescentes participen en el Consejo de Política Social.

-Implementación de la Estrategia para la prevención y erradicación de las peores formas de trabajo infantil.

-Implementación del plan para la prevención y atención del abuso sexual y maltrato infantil de las NNA.

-Implementación de campañas de difusión de la ruta de prevención para proteger integralmente a NNA en riesgo de reclutamiento.

-Creación de estrategia para la implementación del juego como parte fundamental del desarrollo de las niñas y niños.

Para el Municipio de Miraflores, se formulan los siguientes proyectos o programas:

-Programa de educación llamado Pacto Social, Compromiso de Todos.

-Programa de salud, llamado Pacto Social, Compromiso de Todos.

- Programa de cultura y deporte, llamado Pacto Social, Compromiso de Todos.

-Atención a población vulnerable.

-Desarrollo productivo digno. 
-Fortalecimiento institucional.

En el Municipio de Retorno, se observan los siguientes:

-Programa: Seguridad y justicia (apoyo a la inspección de policía, fortalecimiento en cultura ciudadana y promoción de los deberes y derechos ciudadanos, y operatividad y apoyo de la Comisaría de Familia).

-Programa: Fortalecimiento de las organizaciones comunitarias.

-Programa: Conocimiento científico al servicio de la comunidad.

-Programa: Salud pública a su servicio (implementación de la política sexual y reproductiva y política nacional de salud mental).

-Programa: Dotación para el mejoramiento del servicio educativo.

-Programa: Construcción y/o mejoramiento de la infraestructura educativa.

-Programa: Nutrición estudiantil.

-Programa: Cobertura educativa.

-Programa: Formación para la calidad educativa.

-Programa: Formación artística y cultural.

-Programa: Dotación para el fomento de las artes.

-Programa: Fomento deportivo y recreativo.

-Programa: Agua potable y saneamiento básico.

-Programa: Vivienda digna y a su servicio.

-Programa: La administración al servicio de la infancia, adolescencia y la familia.

-Programa: Atención integral a la población víctima del conflicto armado interno.

-Programa: Fortalecimiento a las comunidades indígenas.

Conforme lo expuesto, a continuación, se revisará los planes de gobierno del período 2012-2015, con la finalidad de determinar si se crearon planes, programas, proyectos, estrategias para la prevención del reclutamiento ilegal de los NNA, en los siguientes municipios del departamento de Guaviare:

\section{a. a. Municipio de Calamar}

El Plan de Desarrollo Municipal de Calamar - Guaviare "Juntos por el Desarrollo" 2012- 2015, se encuentra el siguiente programa:

- - Programa: Juntos Garantizando Los Derechos De Las Niñas, Niños y 
Adolescentes, en el cual se resalta los siguientes sub programas: a). JUNTOS POR EL DESARROLLO DE LA PRIMERA INFANCIA, cuyo objetivo es promover y garantizar el desarrollo infantil de las niñas y niños de la primera infancia articulando planes, programas, proyectos y acciones para el cumplimiento efectivo de sus derechos; b). JUNTOS POR EL DESARROLLO DE LA INFANCIA Y ADOLESCENCIA, sus objetivos son: generar espacios de participación para las niñas, niños y adolescentes, garantizar la protección de las niñas, niños y adolescentes, prevenir el reclutamiento y utilización de niños, niñas $\mathrm{y}$ adolescentes por parte de los grupos armados organizados al margen de la ley y de otros ( con este último se busca implementación de campañas de difusión de la ruta de prevención para proteger integralmente a niños, niñas y adolescentes en riesgo de reclutamiento) y garantizar el desarrollo de las niñas y niños a través del juego como derecho fundamental.

A nivel funcional, en la Secretaria de Gobierno y Administrativa, le fue delegada las funciones de coordinar, formular, dirigir y ejecutar políticas, planes, programas y proyectos en materia de seguridad y convivencia ciudadana, salud, educación, gestión del riesgo, grupos vulnerables (infancia, juventud, genero, grupos étnicos, familias en acción, red unidos, población víctima, adulto mayor, población en condición de discapacidad, población LGTBI) participación ciudadana, fortalecimiento de organizaciones sociales y comunitarias. Coordinar los planes, programas y proyectos de cultura, deporte, turismo, recreación, y el desarrollo de la parte administrativa y de personal de conformidad con las normas constitucionales y legales vigentes.

Al consultar la información que reposa en la página web del municipio se observa que, para el caso de los programas, no aparece ninguno relacionado, y en el caso de los proyectos, no existe información respecto a esta dependencia.

Aun así, en el informe de rendición de cuentas presentado por el alcalde Pedro Pablo Nova Bernal, en mayo de 2016, se observa que dentro del programa denominado Municipio incluyente con infancia y adolescencia para volver a creer, cuya meta es la actualización e implementación de la política pública de primera infancia, infancia y adolescencia, se realizó un contrato de mínima cuantía (\$19.055.400), cuyo objeto es la dotación de material didáctico para los hogares y madres comunitarias del Municipio de Calamar. 


\section{a. b. Municipio de Miraflores.}

Los lineamientos programáticos estipulados en este documento del Plan de Desarrollo MIRAFLORES, 2012 -2015 MIRAFLORES: UN PACTO SOCIAL, COMPROMISO DE TODOS, contemplan el programa denominado ATENCION A LA POBLACION VULNERABLE, UN PACTO SOCIAL COMPROMISO DE TODOS, el cual tiene como uno de sus objetivos la prevención del reclutamiento y utilización de niños, niñas y adolescentes por parte de los grupos armados organizados al margen de la ley y de otros grupos delictivos organizados.

En los informes de gestión de los años 2012, 2013 y 2014, documentos digitales que reposan en la página web de este ente territorial, se observa que de manera concreta no se relaciona convenios o contratos que desarrollen la política pública en materia de prevención de reclutamiento de los NNA a nivel local.

\section{a. c. Municipio de Retorno.}

El Plan de Desarrollo para el municipio de El Retorno, para el periodo 20122015, denominado "Un Gobierno a su Servicio" contempla el siguiente programa denominado: La administración al servicio de la infancia, adolescencia y la familia, cuyo objetivo es la prevención de reclutamiento forzado de niños, niñas y adolescentes.

Su objetivo principal es el Diseñar e Implementar programas para Prevenir el reclutamiento y utilización de niños, niñas y adolescentes por parte de los grupos armados organizados al margen de la ley y de otros grupos delictivos organizados y Diseñar e implementar estrategias de prevención de la violencia contra NNA.

Igual que ocurre con el Municipio de Miraflores, se observa que de manera concreta no se relaciona convenios o contratos que desarrollen la política pública en materia de prevención de reclutamiento de los NNA a nivel local.

\subsubsection{Diagnóstico de la política pública en materia de prevención del reclutamiento ilícito de NNA en los Municipios de Calamar, el Retorno y Miraflores del Departamento de Guaviare.}

La Vicepresidencia de la República, Ministerio de Educación Nacional, 
Ministerio Salud y Protección Social, el Departamento Nacional de Planeación, el Departamento Administrativo para la Prosperidad Social y el Instituto Colombiano de Bienestar Familiar, elaboraron un documento informativo denominado Lineamientos de Política Pública para el Desarrollo de los Niños, Niñas y Adolescentes en el Departamento y el Municipio, con el fin de orientar una acción coordinada y articulada dirigida a concretar acciones tendientes al reconocimiento de los niños, las niñas y los adolescentes como sujetos de derechos bajo una trayectoria conceptual, analítica, cultural y política, que transforme y reconozca el lugar y papel de niños, niñas y adolescentes en la familia y la sociedad, obligando a visibilizar a los administradores locales, las responsabilidades y agentes garantes de su bienestar y desarrollo, así como las contribuciones que generen la incorporación de esta prioridad en la agenda política de corto, mediano largo plazo y en las inversiones públicas del municipio, distrito y departamento, para esta población.

El artículo 204 de la Ley 1098 de 2006, ordena a los alcaldes y gobernadores, como mandatarios territoriales y responsables principales del cumplimiento de los derechos de niñas, niños y adolescentes, contar con una política pública diferencial y prioritaria de infancia y adolescencia que propicie la articulación entre los Concejos Municipales, Asambleas y Congreso Nacional, para garantizar la definición y asignación de los recursos para la ejecución de la política pública propuesta (Vicepresidencia de la República, 2015, pág. 32).

El Plan de Desarrollo en una entidad territorial que aún no cuenta con una Política de Infancia y Adolescencia, como es el caso de los Municipios de Calamar, Retorno y Miraflores del Departamento de Guaviare, deben sus representantes incluir en los planes de desarrollo la política de infancia y adolescencia, con los contenidos diagnósticos, estratégicos y de inversiones, las reflexiones, decisiones y acciones que se tomará en el corto, mediano y largo plazo, para garantizar y hacer efectiva la realización de los derechos de los NNA en el municipio, para lo cual es necesario la creación de lineamientos técnicos, en los que se definen el proceso y contenido mínimos que contener el plan de desarrollo, para luego convertirlo en acciones propias de la gestión pública, como proceso integral a través de sus tres componentes principales: planear, ejecutar y evaluar. De allí que se predique que los planes de desarrollo son mapas de ruta y no una simple proyección presupuestal, ante las articulación de acciones de los diferentes sectores para garantizar los derechos de infancia y adolescencia no solo en los 4 años del mandato del alcalde, sino en los próximos periodos, dando así, continuidad y sostenibilidad, esta es la razón por la cual, la política pública en esta materia no puede entenderse como de corto plazo.

El Departamento Nacional de Planeación -DNP - es la entidad competente para orientar el proceso de planificación en las entidades territoriales; según este ente, los pasos que facilitarán la formulación del componente de infancia y adolescencia en el Plan de Desarrollo Municipal, comprenden las siguientes secciones:

1. Designación del coordinador y el equipo responsable de todo el proceso para formular, ejecutar y evaluar el Plan. 


\section{Definición del objetivo final.}

3. Creación de espacios de participación ciudadana, con el ánimo de realizar por parte del coordinador y el equipo responsable un registro de los aportes dados por la comunidad y los diversos organismos con respecto a la construcción de la política de infancia y adolescencia, hasta establecer una imagen del punto de llegada que sirva como marco de objetivo.

4. Organización y análisis de información de lo que se está haciendo en el municipio para el ejercicio de los derechos de los niños, niñas y adolescentes y para conocer la capacidad de respuesta que tienen las instituciones que manejan esta problemática. En esta etapa se definen los procedimientos para que el equipo coordinador sistematice la información.

5. Organización y análisis de las evidencias que reflejan el estado de la situación actual de la infancia y la adolescencia de cara a los objetivos planteados, elaborando de este modo un diagnóstico.

6. Identificación de alternativas posibles para lograr el objetivo propuesto y establecimiento de las metas con el equipo de gobierno, que se pueden alcanzar durante su administración, dados los apoyos y alianzas que ha conseguido alrededor de los objetivos de política de infancia y adolescencia.

7. Redactar el plan incluyendo el gran ideal a conseguir, la imagen de lo que será logrado en la administración, el análisis de la capacidad institucional, el diagnóstico de la situación y las propuestas de acción con las metas que serán alcanzadas, para ser difundido masivamente y sometido a la aprobación del Concejo Municipal.

8. Con base en el plan, se orienta la ejecución de las acciones por parte de todos los organismos involucrados. De igual manera hay que instaurar además mecanismos de seguimiento y evaluación que permitan comparar los resultados de la ejecución con la situación inicial y con la situación alcanzable prevista. (Departamento Nacional de Planeación, Dirección de Desarrollo Territorial Sostenible, 2007).

Conforme lo anteriormente expuesto, en el departamento de Guaviare se resalta la labor de la alcaldía municipal de San José de Guaviare, al lograr avanzar en el proceso de implementación de políticas públicas para la prevención del reclutamiento ilícito de los NNA, cuando a través de la ejecución del contrato no.305-2014, se elaboró el plan de prevención y atención de reclutamiento forzada con enfoque diferencial 2014- 2015, en el que se concibió como objetivo general la articulación de estrategias integrales mediante la coordinación interinstitucional en cumplimiento a las obligaciones del estado en materia de prevención y atención del reclutamiento forzado con enfoque diferencial, dirigidas a las comunidades de mayor vulnerabilidad al riesgo por el conflicto armado en el municipio de San José del Guaviare. 
De este se desprende los siguientes objetivos específicos:

$\square$ Identificar zonas y poblaciones en riesgo del conflicto armado y su influencia en los factores sociales, económicos, políticos y psicológicos de acuerdo a la afectación de las violaciones de los derechos a la vida, libertad, integridad y seguridad en el municipio de San José del Guaviare.

$\square$ Definir la respuesta operativa y de gestión mediante la apropiación de las rutas para la prevención, protección y atención a víctimas o personas en riesgo del marco del reclutamiento forzado.

$\square$ Conocer el proceso de la exoneración del servicio militar obligatorio, socializando los requisitos para la inscripción y obtención de la libreta militar.

$\square$ Identificar una efectiva y pertinente oferta institucional de forma organizada, integrando el enfoque diferencial, de acuerdo a sus competencias y planes de acción, a fin de asegurar la prevención temprana, urgente y protección para la mitigación de los daños y el restablecimiento de derechos de las víctimas en el municipio de San José del Guaviare.

$\square$ Presentar acciones y mecanismos de seguimiento institucional establecidos con la finalidad de evaluar el impacto resultado de la implementación del plan (San José de Guaviare, 2014).

Ahora, al observarse el contenido de este documento, se detecta que en la construcción del mismo se efectúo con los capítulos necesarios para la formulación de un plan de política pública en esta temática, al ser expuestos de manera concreta: información general del territorio, el marco normativo y el enfoque de la prevención y la protección, la georreferenciación de factores de riesgo y dinámica del conflicto armado interno, la caracterización de la población y el grado de vulnerabilidad de la población específicas y de especial protección constitucional, sistema de garantías: consolidación de oferta nacional, acciones y articulación de cada nivel de gobierno para evitar o mitigar el riesgo, las acciones específicas que respondan a las recomendaciones realizadas por el ministerio del interior, la comisión intersectorial de alertas tempranas-ciat y el sistema de alertas tempranas -siat, la identificación de procesos y procedimientos a implementarse a través del comité municipal de justicia territorial y de las instituciones, las rutas de atención, el plan operativo con objetivos, metas, financiación y resultados, y los indicadores de medición, seguimiento y evaluación.

En pocas palabras, este puede considerarse un buen ejemplo práctico y real de gestión de política pública en prevención de reclutamiento ilícito de NNA, caso contrario se predica en cuanto lo desarrollado por los municipios de Calamar, Miraflores y el Retorno, pues si bien es cierto, que en los planes de gobierno consignaron un aparte respecto a esta temática, en la práctica al revisarse los informes 
de gestión y rendición de cuentas, especialmente los relativos a los años 2012 al 2015, se deduce que poco se ha avanzado en la implementación de la política pública en favor de los NNA, siendo palpable que no siguen los derroteros establecidos por el Departamento de Planeación Nacional para la creación y ejecución de planes de gobierno, y las rutas establecidas por el la Secretaria Técnica Intersectorial para la prevención del reclutamiento ilícito, ni mucho menos existe los lineamientos técnicos básicos en ese sentido.

Unos de los aspectos a tener en cuenta de lo observado, hace alusión al presupuesto municipal, por cuanto los entes territoriales mencionados consideran en la mayoría de programas ejecutados diferentes al señalado en esta investigación, la falta de presupuesto municipal para financiar los mismos. Es difusa la articulación de los entes competentes en el manejo de esta problemática, y es muy poca, casi inexistente la información con la que se pueda determinar de manera concreta lo realizado en este ámbito.

De lo expuesto, puede extraerse como conclusión que para el caso de los municipio analizados, aclarando que existe un gran vacío informativo, al no encontrarse datos referentes al objeto de investigación, que los planes de desarrollo de estos entes territoriales, no cumplen con los cinco componentes mínimos necesarios para formular una política pública de primera infancia, infancia y adolescencia que cumpla con los lineamientos normativos establecidos en el Código de Infancia y Adolescencia

-No existe un proceso de sensibilización y análisis del contexto situacional y territorial; en los planes de desarrollo solo se limitan a mencionar uno o pocos programas o planes en esta materia. Pero el proceso de gestión pública previa, no se realiza las etapas consistentes al contacto inicial, identificación de actores, conformación y calificación del grupo líder, análisis de contexto territorial y proceso de formación.

-En el segundo componente, se abarcan las decisiones de política de primera infancia, infancia y adolescencia que responden a: identificación de problemas relevantes, prioridades en clave del ciclo vital, familia y el sueño colectivo hacia la protección integral de los niños, las niñas y los adolescentes. No hay evidencia que se corrobore la realización de estas tareas.

-En cuanto al componente tres que trata el plan de gestión de la política pública que responde a: objetivos, acciones, metas, indicadores, recursos y responsables en el corto, mediano y largo plazo, tan solo en el Municipio de San José de Guaviare, ha logrado llegar a esta etapa.

-El cuarto componente es el seguimiento que responde a un proceso continuo de análisis y recolección de información, indicadores y control en el marco de la Política Pública. No es claro quien asume esta responsabilidad 
-Finalmente, en el quinto componente está la rendición pública de cuentas que presenta el proceso de rendición pública de cuentas para la garantía de derechos, su obligatoriedad según la Ley 1098 de 2006 y los pasos para realizarla. Las actividades efectuadas por estos entes territoriales, no se menciona de manera concreta en sus informes de gestión y rendición de cuentas que se haya implementado esta política pública.

De lo expuesto puede inferirse, que en el ámbito político a nivel nacional se destaca la elaboración del marco para las políticas públicas y los lineamientos para la planeación del desarrollo de la infancia y la adolescencia, así como los lineamientos de política pública de juventud; la expedición del Plan Nacional para la Niñez y la Adolescencia 2009-2019; la conformación y operación de la Mesa Nacional de Infancia y Adolescencia; el proceso de construcción del Sistema Nacional de Seguimiento y Evaluación al cumplimiento de los derechos; el inicio de la institucionalización de la vigilancia y control de la gestión para la garantía de los derechos y del gasto público social dirigido a la niñez y la juventud; y ajustes a la arquitectura institucional expresados en la creación y fortalecimiento de instancias de articulación de la política pública, lineamientos técnicos de diferentes servicios y la cualificación y creación de nuevos programas (UNICEF, 2014).

A nivel territorial, el panorama es distinto, al ser evidente las desigualdades territoriales que se extienden al tema de los derechos humanos, por un lado ante la presencia de un modelo de organización política de descentralización incompleta, al estar construyéndose un gobierno central fuerte frente a gobiernos territoriales en proceso de maduración con varios desafíos en la gestión eficiente y eficaz de sus recursos, planes, programas y proyectos (DNP, 2011).

Ello ha conllevado a la presencia de dificultades en la prestación y cobertura universal de servicios básicos, una alta rotación de funcionarios, una insuficiente representación política y problemas de coordinación, de gestión e implementación para la atención integral de niños, niñas y adolescentes, inadecuado proyección presupuestal, e indebida articulación de los organismos que tratan esta problemática.

Realmente, para el caso objeto de investigación, es palpable que esos municipios se encuentran dentro de aquellos cuyos planes y políticas públicas específicas en materia de infancia y adolescencia, presenta una serie de dificultades y limitaciones respecto de los procesos de implementación de las mismas en sus distintos niveles de ejecución, tópicos que fueron condesados por la UNICEF, en los siguientes: • Falta de armonización entre leyes, reglamentos y códigos; • La respuesta inercial de la institucionalidad que tiene trayectoria en la implementación de políticas para este ciclo de vida; - La tendencia a la burocratización de los procesos que requieren altas dosis de innovación y de aprendizaje; • El desconocimiento de nuevos marcos conceptuales para la gestión pública especialmente en el campo de la 
aplicación de los enfoques diferenciales y de equidad; - La debilidad en la coordinación, complementariedad y subsidiariedad entre los entres nacionales y locales; - La duplicación de acciones entre entidades al surgir nuevas dependencias con nuevos mandatos, por mencionar algunas (UNICEF, 2014).

\subsection{Hipótesis}

Si existen estrategias para la prevención del reclutamiento ilícito de menores de edad. El Estado Colombiano como garante de la protección de los derechos fundamentales de los niños, niñas y adolescentes, a través de sus políticas públicas busca resolver este problema del conflicto armado en el país por parte de los grupos al margen de la ley.

No obstante, el reclutamiento ilegal de niños, niñas y adolescentes por parte de los grupos armados organizados al margen de la Ley, se vería afectado a medida que se vayan fortaleciendo las estrategias implementadas por el Gobierno Nacional, pero siempre y cuando exista una protección integral a la niñez y se realice un trabajo por parte del Gobierno Nacional enfocado a la familia y la sociedad, tendiente al reconocimiento de los derechos de los niños, niñas y adolescentes, a la vez, prevenir que esos derechos sean amenazados o vulnerados, asegurar la garantía y el cumplimiento de los mismos y restablecer aquellos derechos que han sido vulnerados.

En la actualidad las estrategias implementadas por el Estado tendientes a mitigar este flagelo, al parecer no han arrojado los resultados esperados, debido a que el Gobierno no ha hecho presencia apropiada en todas las regiones del Departamento del Guaviare, es decir, falta de presencia institucional en especial en los Municipios de Calamar, el Retorno y Miraflores, lo que facilita que los menores habitantes de estas regiones sean más vulnerables frente a esta problemática. De igual forma no existen recursos económicos y humanos suficientes que permitan desarrollar diversas estrategias y que lleguen a todos los rincones del Departamento del Guaviare.

Con el fin de reducir este problema, el Estado debe fortalecer las campañas educativas dirigidas a toda la población a nivel regional y en especial en los municipios de Calamar, el Retorno y Miraflores, reforzando los valores en la familia y la sociedad; que se protejan sus espacios vitales, garantizar la educación ya sea presencial o implementado aulas virtuales en zonas rurales y urbanas; fomentar el deporte, la recreación, elaborando y ejecutando proyectos de construcción de escuelas y parques a nivel rural y urbano, establecer la jornada escolar; contrarrestar formas de violencia y explotación ejercidas en su entorno familiar, comunitario y social; que el Estado garantice una adecuada, pertinente, eficaz y asertiva oferta institucional, en lo nacional y territorial, a través del cumplimiento de sus políticas públicas para el pleno ejercicio y garantía de sus derechos y promover su reconocimiento como sujetos de 
derechos en el entorno familiar, comunitario, social y erradicación de los cultivos ilícitos.

Dadas estas variables tanto de la problemática planteada, como de las estrategias implementadas por el Estado, es que se podría aseverar que, aunque se va por buen camino y se están Incrementando bases interesantes para mitigar el reclutamiento de menores, el alcance de los mecanismos en la actualidad es limitado frente a lo que requiere este fenómeno.

\section{CONCLUSIONES}

- La normatividad internacional para la prevención del reclutamiento ilícito de Niños, Niñas y Adolescentes por parte de los GAOML, han sido adoptadas por el marco normativo colombiano, en el cual considera que los NNA que hayan sido reclutados y/o utilizados por parte de los GAOML, son considerados víctimas y tienen derecho al restablecimiento de sus derechos y a la reparación, en el marco de la Ley 1448 de 2011.

- - El Estado Colombiano como garante de la protección de los derechos fundamentales de los NNA a través de sus políticas públicas, ha buscado resolver este problema, no obstante estos instrumentos tendrían una mayor efectividad, si se fortalecieran las estrategias implementadas por el Gobierno Nacional a nivel local, desde un enfoque de protección integral con la realización de un trabajo de interacción entre la familia, el Estado y la sociedad, tendiente al reconocimiento de los derechos de los NNA, asegurando sus garantías y el cumplimiento en materia de protección a sus derechos, junto con la prevención del reclutamiento forzado, y el restablecimiento de aquellos derechos que han sido vulnerados, amenazados o lesionados.

- El Gobierno Nacional durante los años comprendidos del 2010 a 2015 ha venido implementado una política pública tendiente a mitigar este problema, pero a pesar de ello, se han presentado omisiones en algunos aspectos reglados en el Derecho Internacional Humanitario establecidas para frenar este fenómeno, en la medida pocos son los enfoques socioeconómicos que se han creado a través de proyectos, campañas, programas que permitan atacar de forma armónica e integral los diferentes factores que influyen o favorecen el reclutamiento de menores (Colombia, Corte Constitucional, (2008), Auto No. 251, M.P. Cepeda Espinosa M.J., Bogotá) . 
- Este fenómeno social no se ha podido reducir en un porcentaje considerable, ante la débil promoción e implementación de la política desarrollada a nivel nacional en el plano local, para la prevención del reclutamiento ilícito de los NNA ante la falta de articulación de los compromisos y responsabilidades de las entidades públicas locales, nacionales, descentralizadas, basta con observar el panorama del Departamento del Guaviare y en especial en los municipios de Calamar, el Retorno y Miraflores, en donde aún el Estado no ha hecho presencia de manera eficiente.

- Las estrategias implementadas por el Estado tendientes a mitigar este flagelo, al parecer no han arrojado los resultados esperados, debido a que el Gobierno no ha hecho presencia apropiada en todas las regiones del Departamento del Guaviare, es decir, falta presencia institucional en especial en los Municipios de Calamar, el Retorno y Miraflores, lo que facilita que los menores habitantes de estas regiones sean más vulnerables frente a esta problemática. De igual forma no existen recursos económicos y humanos suficientes que permitan desarrollar diversas estrategias y que lleguen a todos los rincones del Departamento.

- - No existe un modelo de medición de riesgos que asocie estadísticamente la magnitud del reclutamiento que permita identificar el tipo de NNA vulnerables a ser reclutados en los tres municipios Retorno, Calamar y Miraflores.

- En la actualidad no se tiene clara la política pública en ese sentido, ante las nuevas expectativas políticas que se puedan implementar en medio de la realidad sociopolítica influenciada entre otros aspectos por el proceso de paz con grupos alzados en armas, eventualidades en las que sería importante verificar si se van a realizar acercamientos, ejecutar programas con la población víctima de este fenómeno, con la participación de otras entidades estatales, con la respectiva asignación de mayores recursos económicos para el Departamento del Guaviare y sus municipios, enfocados a enfrentar y resolver este problema.

- - De otra parte, es importante mencionar que, si bien es cierto que la erradicación del reclutamiento ilícito de NNA es el centro principal del eje focal para la paz, este debe involucrar desde la perspectiva de la justicia restaurativa a los actores princípiales de dicho fenómeno, máxime cuando a través del diálogo se pretende evacuar las diversas implicaciones del conflicto. 
- - Un punto que no se ha tenido en cuenta en las estrategias para prevención es la relativa a las posibles represalias por parte de los grupos armados ante la implementación de la política en el nivel local, junto con obstáculos como lo son la falta de conocimiento de la población para interponer denuncias o solicitar ayudas, la falta de recursos para desplazamientos hacia las cabeceras municipales y la incipiente protección a los denunciantes.

- Con el fin de reducir este problema, el Estado debe fortalecer las campañas educativas dirigidas a toda la población a nivel regional y en especial en los municipios de Calamar, el Retorno y Miraflores, reforzando los valores en la familia y la sociedad; que se protejan sus espacios vitales, garantizar la educación ya sea presencial o implementado aulas virtuales en zonas rurales y urbanas; fomentar el deporte, la recreación, elaborando y ejecutando proyectos de construcción de escuelas y parques a nivel rural y urbano, establecer la jornada escolar; contrarrestar formas de violencia y explotación ejercidas en su entorno familiar, comunitario y social; que el Estado garantice una adecuada, pertinente, eficaz y asertiva oferta institucional, en lo nacional y territorial, a través del cumplimiento de sus políticas públicas para el pleno ejercicio y garantía de sus derechos y promover su reconocimiento como sujetos de derechos en el entorno familiar, comunitario, social y erradicación de los cultivos ilícitos.

-En el departamento de Guaviare, solo la alcaldía municipal de San José de Guaviare, lograr avanzar en el proceso de implementación de políticas públicas para la prevención del reclutamiento ilícito de los NNA, a través de la ejecución del contrato no.305-2014, mediante el cual se elaboró el plan de prevención y atención de reclutamiento forzada con enfoque diferencial 2014- 2015.

-Los Municipios de Calamar, Miraflores, el Retorno, no han adaptado los lineamientos y rutas para la prevención del reclutamiento ilícito de los NNA, como tampoco han elaborado en sus planes de desarrollo, los programas o proyectos para el ejercicio efectiva de una gestión pública en esta materia, el tema solo se expone muy someramente sin que se sigan los parámetros establecidos por el Departamento de Planeación Nacional y los demás organismos que son competentes y encargados de realizar la implementación de esta política pública.

- Dadas estas variables tanto de la problemática planteada, como de las estrategias implementadas por el Estado, es que se podría aseverar que, aunque se va por buen camino y se están incrementando bases interesantes para mitigar el reclutamiento de menores, el alcance de los mecanismos en la actualidad es limitado frente a lo que requiere este fenómeno. 


\section{BIBLIOGRAFÍA}

\section{Normatividad}

Convención de Naciones Unidas sobre los Derechos del Niño.

Congreso de la República, ley 418 de 1997, art. 17.

Congreso de la República, ley 548 de 1999.

Congreso de la República, ley 975 de 2005.

Código de Infancia y Adolescencia, Ley 1098 de 2006.

Decreto 1740 de 2010.

Naciones Unidas, Estatuto de Roma, art. 8 núm. 2 ord. XXVI.

Protocolo Facultativo sobre la participación de los niños en los conflictos armados.

OIT, Convenio 182 sobre la prohibición de las peores formas de trabajo infantil y la acción inmediata para su eliminación.

Naciones Unidas, Estatuto de Roma, art. 8 núm. 2 ord. XXVI.

\section{Jurisprudencia}

Colombia, Corte Constitucional, (2001), Sentencia T-979, M.P. Córdoba Triviño J., Bogotá.

Colombia, Corte Constitucional, (2003), Sentencia C-273, M.P. Dra. Vargas Hernández C., Bogotá

Colombia, Corte Constitucional, (2003), Sentencia C- 318, M. P. Araujo Rentería J., Bogotá 
Colombia, Corte Constitucional (2004), Sentencia T-025, M.P. Cepeda M.

Colombia, Corte Constitucional (2005), Sentencia C-203, M.P. Cepeda M.

Corte Constitucional, Sentencia C-370 de 2006, Magistrados Ponentes: Manuel José

Cepeda Espinosa, Jaime Córdoba Triviño, Rodrigo Escobar Gil, Marco Gerardo Monroy Cabra, Álvaro Tafur Galvis, Clara Inés Vargas Hernández

Colombia, Corte Constitucional (2008), Auto 251, M.P. Cepeda Espinosa M.J., P. 41

Colombia, Corte Constitucional, (2008), Auto No. 251, M.P. Cepeda Espinosa M.J.

Colombia, Corte Constitucional (2009), Sentencia C-240, M.P. Dr. González Cuervo M., Bogotá.

Colombia, Corte Constitucional, (2010), Sentencia T-572, M. P. Henao Pérez J., Bogotá

\section{Doctrina}

Betancourt M, Ramírez C. (2008), Política pública territorial, ESP, Bogotá.

Cano, (2010), Universidad de Antioquia, Revista Estudios de Derecho No. 149, junio.

Cartilla Comparar Acciones por los derechos del niño (2004) "Niños, niñas y adolescentes vinculados al conflicto armado", p12

Coalico (2007) Informes sobre la situación de niños, niñas y jóvenes vinculados al conflicto armado en Colombia falencias en el proceso de desvinculación de niños, niñas y jóvenes de los grupos paramilitares, p. 9

Coalico, Desmovilización paramilitar: Obstáculos para el acceso a la justicia de las víctimas de reclutamiento ilícito, ponencia presentada en el evento organizado por la cooperación alemana GIZ en Julio de 2011. 
Convenio Defensoría del Pueblo - Unicef, (2006) informe defensorial "Caracterización de los niños, niñas y adolescentes desvinculados de los grupos armados ilegales: inserción social y productiva desde un enfoque de derechos humanos"

Comité de los Derechos del Niño (2006). Observaciones finales sobre Colombia. Documento de las Naciones Unidas CRC/C/COL/CO/3, 8 de junio de 2006, párrafo 80

Comisión Colombiana de Juristas, (2009), Coalición contra la vinculación de NNA al conflicto armado en Colombia

Defensoría del Pueblo (2014) Prevención del Reclutamiento de los NNA, análisis de la política pública con enfoque étnico y Defensoría del Pueblo, Informe Defensoría Prevención de Reclutamiento de NNA Análisis de la Política Pública con enfoque étnico

Defensoría del Pueblo, 2014, Informe Defensorial Prevención del Reclutamiento de Niños, Niñas y Adolescentes, Análisis de la Política Pública con Enfoque Étnico

Defensoría del Pueblo (2012), Informe especial de riesgo sobre reclutamiento y utilización ilícita de NNA en el sur oriente colombiano: Meta, Guaviare, Guaina y Vichada.

Departamento Nacional de Planeación (2010) CONPES 3673 de 2010, por medio del cual se establece la política pública de prevención del reclutamiento y utilización de NNA por parte de los grupos armados organizados al margen de la ley y grupos delictivos organizados, Bogotá.

Departamento Nacional de Planeación, Dirección de Desarrollo Territorial Sostenible, (2007) "El proceso de planificación en las entidades territoriales: El plan de desarrollo y sus instrumentos para la gestión 2008 - 2011". Versión borrador en medio magnético, 30 de mayo.

Gobernación de Guaviare, (2012) Plan de Desarrollo Departamental Así Marcamos Huella, 2012-2015

Gobernación de Guaviare, 2012, Proyecto de Ordenanza Plan de Desarrollo 
Departamental, 2012- 2015

Human Rights Wath, 2003.

ICBF, (2013) Cartilla Observatorio del Bienestar de la Niñez No. 9

Naciones Unidas (2008), Hechos del Callejón, No. 38, Año 4, Bogotá

Oficina del Alto Comisionado de las Naciones Unidas para los Derechos Humanos, Módulo Los Derechos Económicos, Sociales y Culturales, Nueva York, Ginebra, pág. 33

Secretaria Técnica Intersectorial para la prevención del reclutamiento, la utilización y la violencia sexual contra niños, niñas y adolescentes por parte de grupos armados al margen de la ley y grupos delictivos organizados, (2015), Cartilla Construcción de un Plan de Protección Integral de Niños, Niñas y Adolescentes.

Secretaria Técnica de la Comisión Intersectorial, (2015) Cartilla Estrategias para la focalización de acciones: Insumos para la prevención del Reclutamiento y la violencia Sexual

Secretaria Técnica de la Comisión Intersectorial (2015), Prevención del reclutamiento, la utilización y la violencia sexual contra niños, niñas y adolescentes por parte de grupos armados al margen de la ley y grupos delictivos organizados.

Springer N. (2012), Como corderos entre lobos. Del uso y reclutamiento de niñas, niños y adolescentes en el marco del conflicto armado y la conspiración criminal en Colombia.

UNICEF, 2004, Guía del Protocolo Facultativo sobre la Participación de Niños, Niñas en los Conflictos Armados.

Vicepresidencia de la República, DNP, OIM, Equipo Técnico Interinstitucional, (2011).

Yaffe, Lilian, (2011) "Conflicto armado en Colombia: análisis de las causas económicas. 
Ministerio de la Protección Social (2009), Plan Nacional para la Niñez y la Adolescencia.

\section{Documentos publicados en web}

Amnistía Internacional, (2008), Los niños y la tortura, Recueprado el 15 de noviembre de $2016 \quad$ de www.amdh.org.mx/mujeres/menu_superior/Doc_basicos/5_biblioteca_virtual/9_infor mes/Otros/40a/1.pdf . 27 de Marzo de 2008. 24 p.).

COALICO, (2013), Coalición contra la Vinculación de Niños, Niñas y Jóvenes al Conflicto Armado Colombiano, Recuperado el 15 de noviembre de 2016, de http://www.coalico.org/publicaciones/documento1.htm

Consejería DDHH, Presidencia de la República, Secretaría Técnica de la Comisión Intersectorial de Prevención del Reclutamiento y Utilización de Niños, Niñas y Adolescentes, (2012) Recuperado el 20 de enero de 2017, tomado de http://historico.vicepresidencia.gov.co/Iniciativas/Paginas/PrevencionReclutamiento.a $\underline{\mathrm{spx}}$

CNMH, (2018), Informe Una guerra sin edad, Recuperado el 10 de agosto de 2018, tomado de https://colombia2020.elespectador.com/pais/el-reclutamiento-forzado-de-menores-encifras

Defensoría del Pueblo, Elementos de análisis normativo para la comprensión de la vinculación de niños, niñas y adolescentes a grupos armados ilegales, Recuperado el 18 de marzo de 2017 de https://www.unicef.org/colombia/pdf/co_resources_ID9_conclus.pdf

Diccionario Virtual, Tomado de Internet https://es.oxforddictionaries.com/definicion/reclutar, Recuperado el 13 de noviembre de 2016

Nullvalue, (2016), El Origen del Conflicto Armado, Periódico el Tiempo, Recuperado $\begin{array}{llllll}\text { el } & 20 & \text { de } & \text { mayo } & \text { de }\end{array}$ http://www.eltiempo.com/archivo/documento/MAM-1014581 
Hernández R, 2014, Recuperado el 13 de noviembre de 2016, Tomado de Internet https://miradasporeldesarrollo.wordpress.com/tag/principios-ciudad-del-cabo/.

Organización Internacional para las Migraciones, USAID, Fuente: ABC sobre la prevención del reclutamiento de NNA por parte de grupos armados y organizados al margen de la ley y grupos delictivos organizados, Recuperado el 13 de enero de 2017,Tomado de Internet http://repository.oim.org.co/handle/20.500.11788/397

Unidad para la Atención y Reparación Integral de Victimas 2012, Recuperado el 15 de noviembre de $2016 \quad$ de file:///D:/Downloads/cartilla\%20del\%20guaviare\%20estadisticaGuaviare.pdf

USAID, Recuperado el 13 de noviembre de 2016, Tomado de Internet http://repository.oim.org.co/handle/20.500.11788/397.

USAID, OIM, Cartilla ABC sobre la prevención del reclutamiento de los niños, niñas y adolescentes por parte de los grupos armados organizados al margen de la ley y grupos delictivos organizados, Recuperado el 15 de noviembre de 2016, Tomado de OIMfile://C:/Users/ABOGADO/Google\%20Drive/INVESTIGACIONES/Reclutami ento\%20ilegal\%20menores/abc_prevencion_reclutamiento.pdf. 